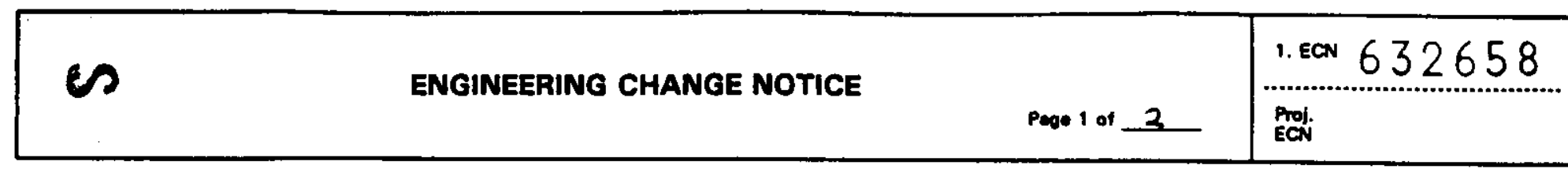

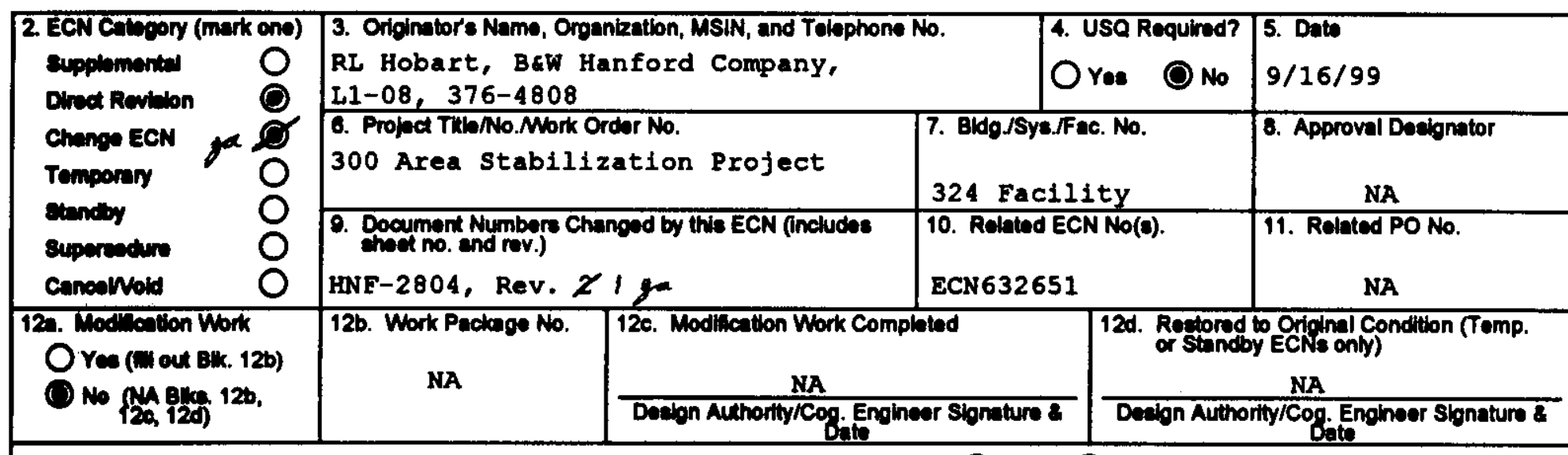

130. Decortiplon of Change

13b. Dedion Baseline Document? O Yes $O$ No

Complete revision of document.

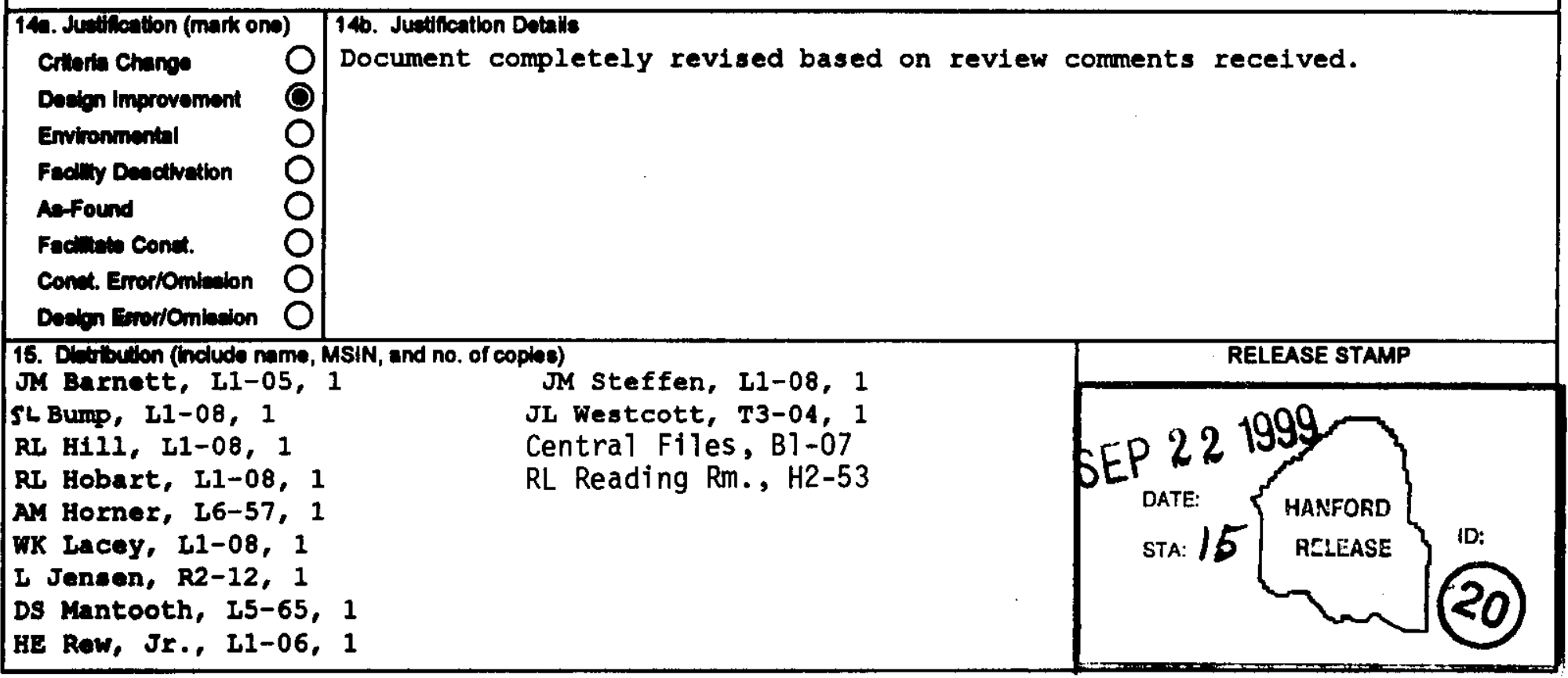




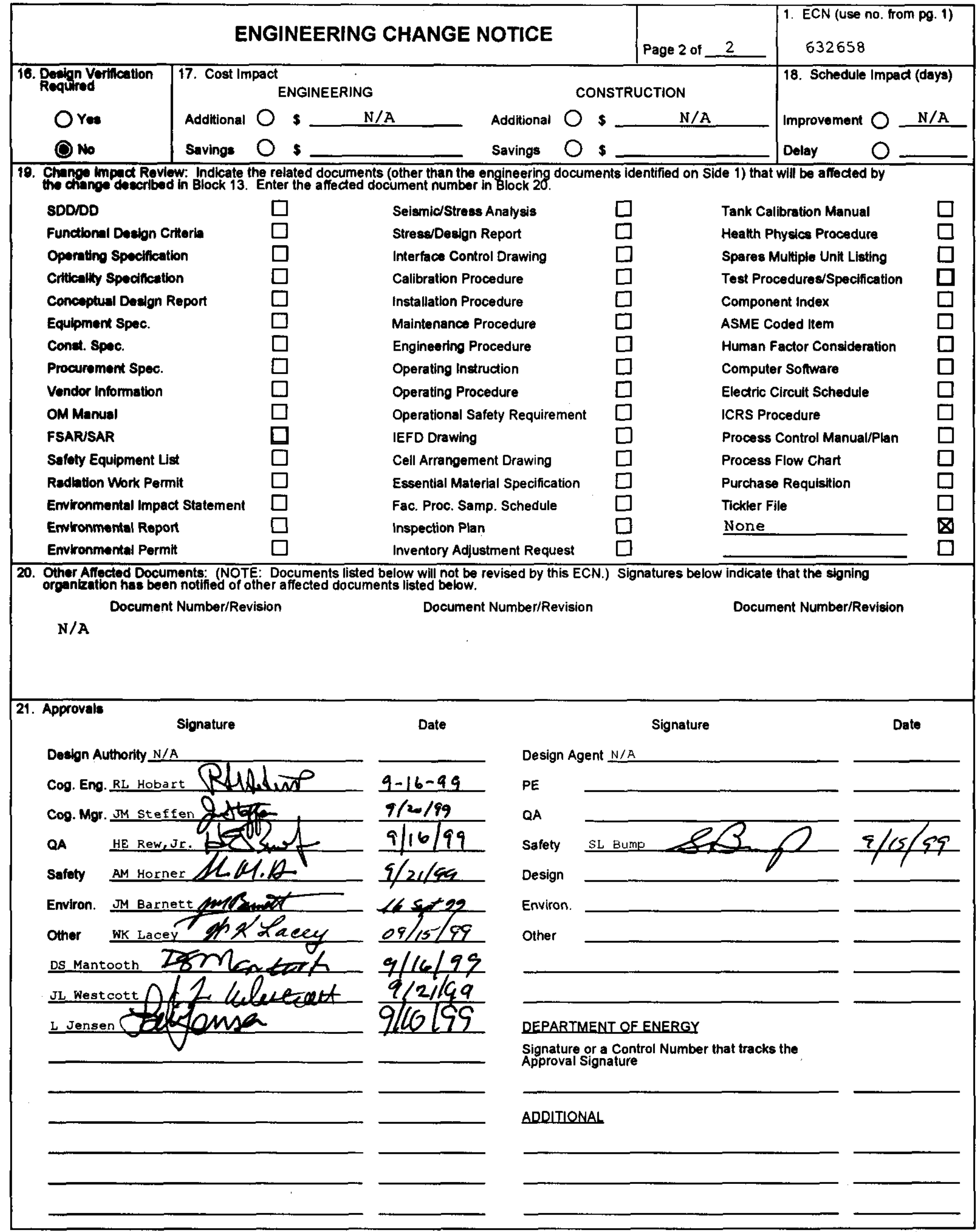


HNF-2804, Rev. 2

September 1999

\title{
B-CELL WASTE CLASSIFICATION SAMPLING AND ANALYSIS PLAN
}

\author{
RL Hobart
}

RL Hill

B\&W Hanford Company, Richland, WA 99352

U.S. Department of Energy Contract DE-AC06-96RL13200

$\begin{array}{llll}\text { EDT/ECN: } & 632658 & \text { UC: } & 2000 \\ \text { Org Code: } & 19400 & \text { Charge Code: } & 101031 \text { GA00 MN990151 } \\ \text { B\&R Code: } & \text { EW31300000 } & \text { Total Pages: } & 5657\end{array}$

Key Words: Sampling and Analysis Plan, Data Quality; Low-Level Waste; Transuranic; Decontamination Factor; Alpha Energy Analysis; Gamma Energy Analysis.

Abstract: This report documents the methods used to collect and analyze samples to obtain data necessary to verify and/or determine the radionuclide content of the 324 Facility B-Cell decontamination and decommissioning waste stream.

TRADEMARK OISCLAIMER. Reference hereln to any specific commerclal product. process. or service by trade name. trademark. manufacturer. or otherwise. does not necessarily constitute or imply its endorsement. recormendation. or favoring by the United States Government or any agency. thereof or its contractors or subcontractors.

Printed in the United States of America. To obtain coples of this document, contact: Document Control Services. P.0. Box 950. Mallstop H6-08. Richland WA 99352. Phone (509) 372-2420: Fax (509) 376-4989.

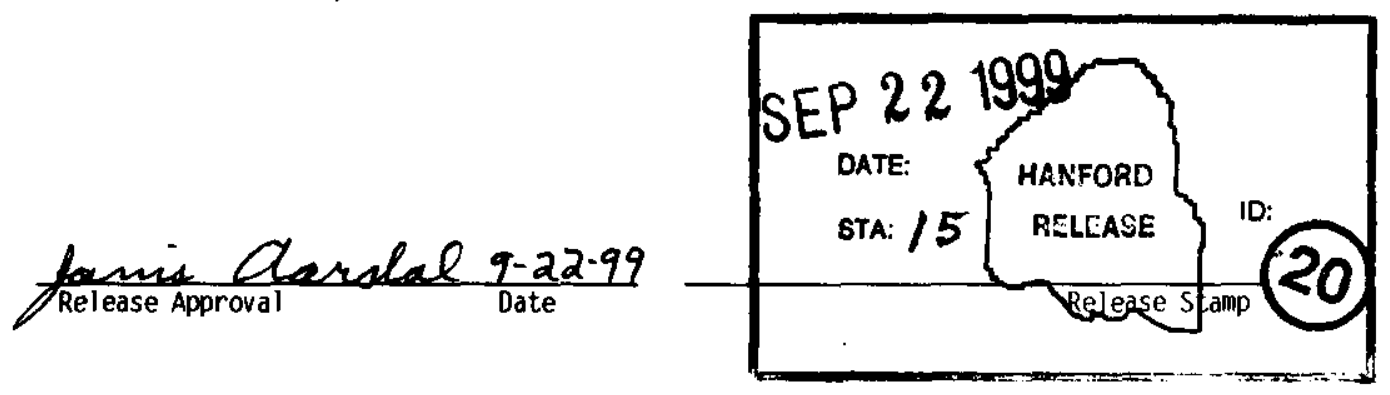




\section{RECORD OF REVISION}

Page 1

(2) Tith

B-CELL WASTE CLASSIFICATION SAMPLING AND ANALYSIS PLAN

Change Control Record

(3) Roviation

(4) Description of Change - Replace, Add, and Delete Pages

\begin{tabular}{|c|l}
\hline 0 & $\begin{array}{l}\text { (7) } \\
\text { Initial Issue; EDT-625901 }\end{array}$ \\
\hline 1 & First Re-Issue; ECN-632651 \\
\hline 2 RS & Complete Revision; ECN-632658 \\
\hline
\end{tabular}

Authorized for Release

\begin{tabular}{l|l} 
(5) Cog. Engr. & (6) Cog. Mgr. Date
\end{tabular}

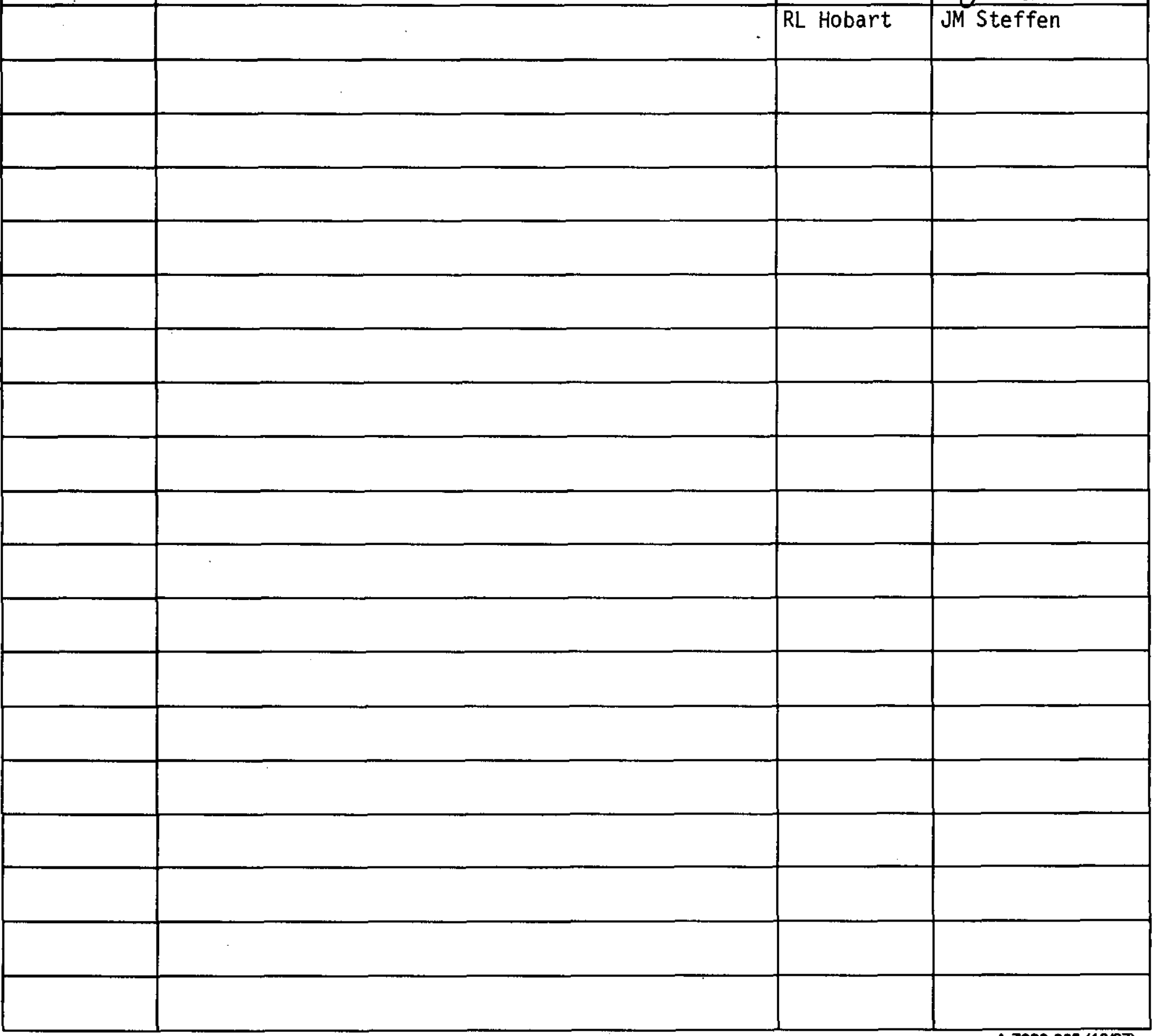




\section{RELEASE AUTHORIZATION}

Document

Number :
HNF-2804, Rev. 2

B-Cell Waste Classification Sampling and Analysis Plan

This document, reviewed in accordance with DOE Order 241.1, "Scientific and Technical Information Management," and 241.1-1, "Guide to the Management of Scientific and Technical Information," does not contain classified or sensitive unclassified information and is:

\section{APPROVED FOR PUBLIC RELEASE}

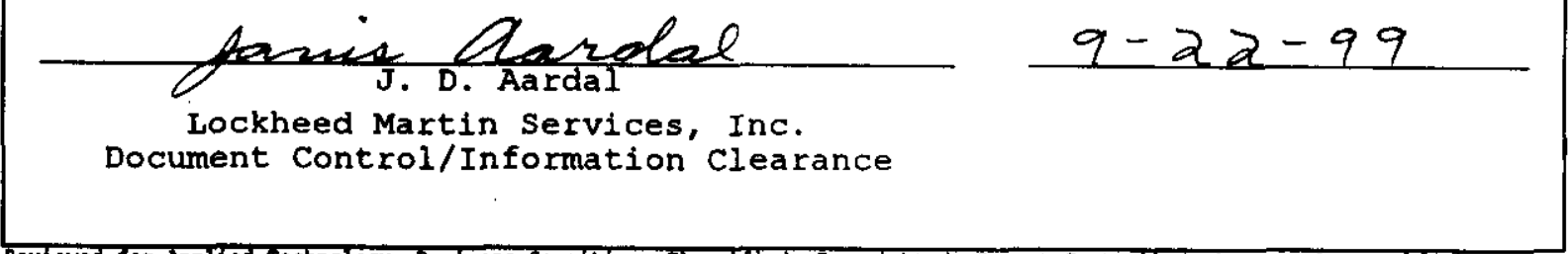

Roviowed for Applied Tochnology, Bus Iness Sengltive, Classified, Copyrighted, Export Controlled, Patent, Personol/Private, Proprietary, Protected CRADA, Trademark, Unclassifiod Controlled Nuclear Information.

Tradenark Dieclaleer. Reference herein to any specific commercial product, process, or service by trade name, trademark, manufacturer, or otherwise, does not necessarily constitute or imply its endorsement, recommendation, or favoring by the expressed herein do not necesyarily state or reflect those of the United St ates Government or any agency thereof. This repert has been reproduced from the best ovailable copy.

Printed in the United States of America. 
HNF-2804, Rev. 2

September 1999

\section{TABLE OF CONTENTS}

Table of Contents

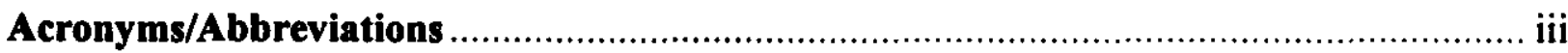

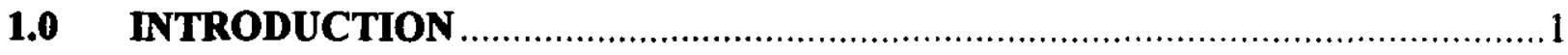

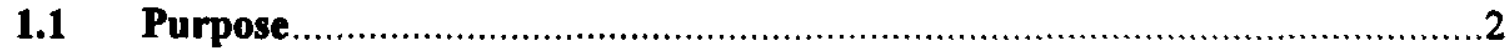

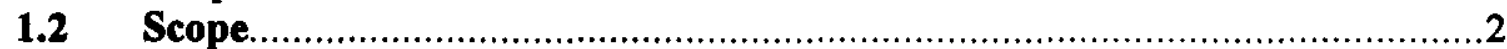

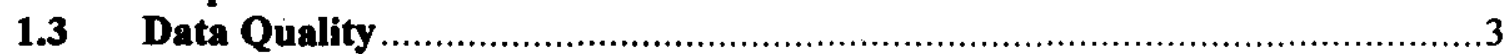

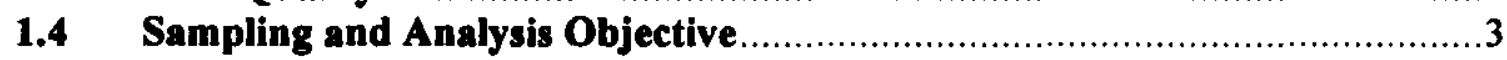

1.5 B-Cell Description and Background ..............................................

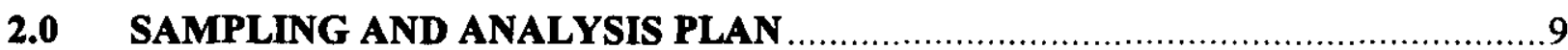

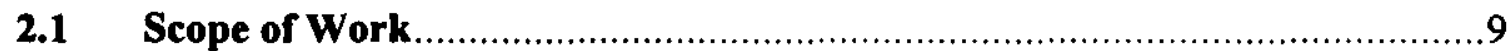

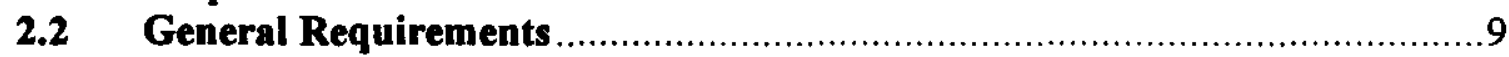

2.3 Sample Location and Frequency ................................................ 10

2.4 Sample Designation, Handling and Custody .................................17

2.5 Sample Collection and Analysis .................................................. 17

2.6 Fixed Contamination Layer Removal Study .................................... 19

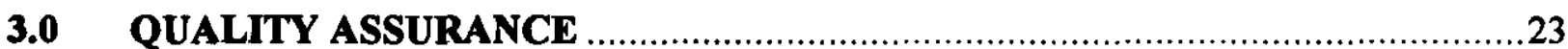

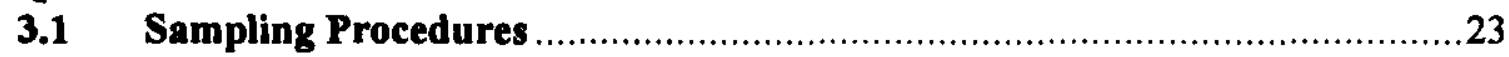

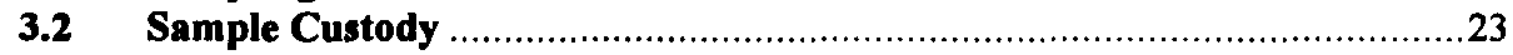

3.3 Analytical Procedures for Waste Characterization Samples ....................24

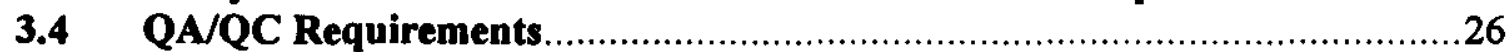

3.5 Data Reporting and Management .............................................. 28

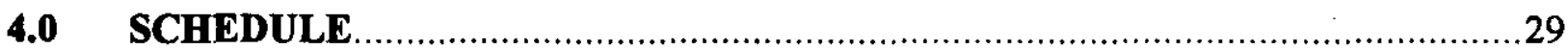

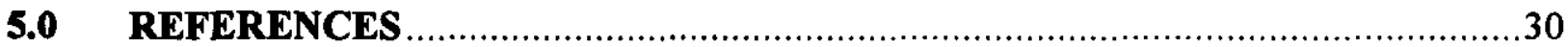

APPENDIX A - DATA QUALITY PROCESS SUMMARY ....................................

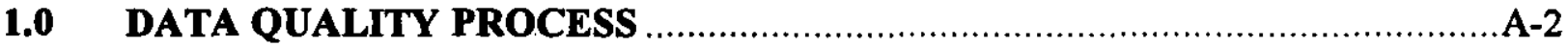

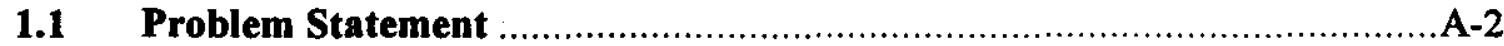

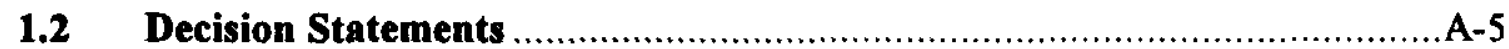

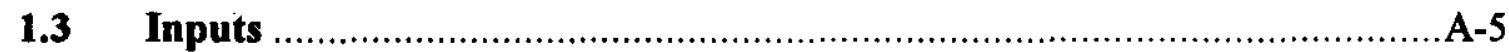

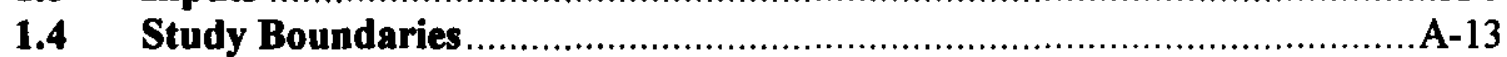

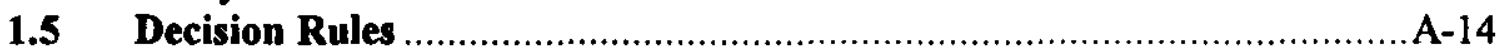

1.6 Tolerable Limits on Decision Errors .......................................... A-14

1.7 Optimization of Sampling and Analysis Design .............................. A-14 


\section{LIST OF FIGURES}

Figure 1. Overall B-Cell Characterization Document Scheme ..........................................1

Figure 2. Contributions to the Measured Dose Rate of B-Cell Waste In Grout .....................6

Figure 3. General Methodology Used to Calculate Isotopic Content of B-Cell

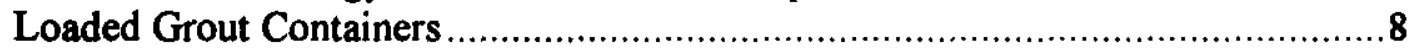

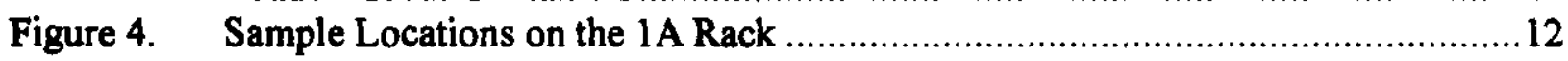

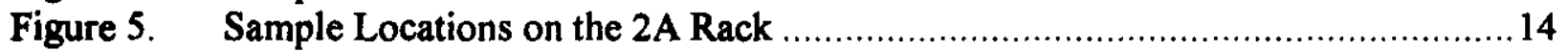

\section{LIST OF TABLES}

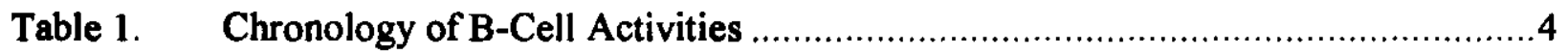

Table 2. Summary of Smear Data Used in Previous Technical Basis for

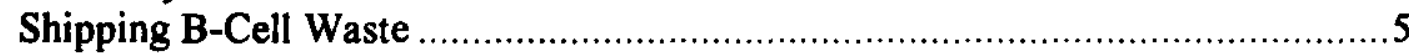

Table 3. Operating Procedures and Technical Work Documents for Sampling and Handling of B-Cell Metal Rack Samples .17

Table 4. Decontamination Reagents to be Tested in Fixed Contamination Layer Removal Study .20

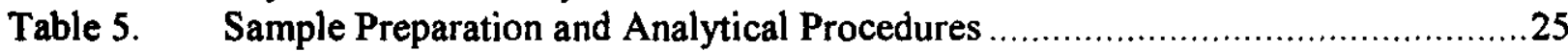

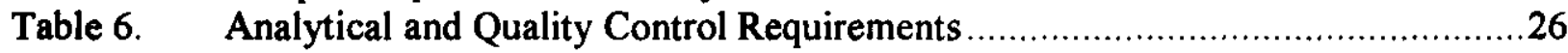

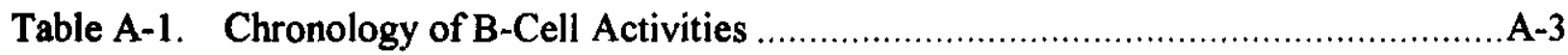

Table A-2. Applicable Conversion Factors for General Radiological Calculations............A-10

Table A-3. Applicable Low-Level Burial Grounds Radiological Content Limits...............A-10

Table A-4. Analytical and Quality Control Requirements ..........................................A-16 


\section{ACRONYMS/ABBREVIATIONS}

\begin{tabular}{|c|c|}
\hline${ }^{3} \mathbf{H}$ & Tritium \\
\hline${ }^{14} \mathrm{C}$ & Carbon-14 \\
\hline${ }^{36} \mathrm{Cl}$ & Chlorine-36 \\
\hline${ }^{60} \mathrm{Co}$ & Cobalt -60 \\
\hline${ }^{79} \mathrm{Se}$ & Selenium-79 \\
\hline${ }^{90} \mathrm{Sr}$ & Strontium-90 \\
\hline${ }^{90} \mathbf{Y}$ & Yttrium-90 \\
\hline${ }^{93} \mathrm{Mo}$ & Molybdenum-93 \\
\hline${ }^{99} \mathrm{Tc}$ & Technetium-99 \\
\hline${ }^{129} \mathrm{Sb}$ & Antimony-125 \\
\hline${ }^{129} \mathrm{I}$ & Iodine-129 \\
\hline${ }^{137} \mathrm{Cs}$ & Cesium-137 \\
\hline${ }^{137 m} \mathrm{Ba}$ & Barium-137m \\
\hline${ }^{154} \mathrm{Eu}$ & Europium-154 \\
\hline${ }^{155} \mathrm{Eu}$ & Europium-155 \\
\hline${ }^{187} \mathrm{Re}$ & Rhenium-187 \\
\hline${ }^{237} \mathrm{~Np}$ & Neptunium-237 \\
\hline${ }^{238} \mathrm{Pu}$ & Plutonium-238 \\
\hline${ }^{239 / 240} \mathrm{Pu}$ & Plutonium-239 and Plutonium-240 \\
\hline${ }^{241} \mathrm{Am}$ & Amercium-241 \\
\hline${ }^{243} \mathrm{Cm}$ & Curium-243 \\
\hline${ }^{244} \mathrm{Cm}$ & Curium-244 \\
\hline AEA & Alpha Energy Analysis \\
\hline $\mathbf{A P}$ & $2.5 \mathrm{M} \mathrm{NaOH}$ and $0.2 \mathrm{M} \mathrm{KMnO}_{4}$ \\
\hline BWHC & B\&W Hanford Company \\
\hline CI & confidence interval \\
\hline $\mathbf{C i}$ & Curie \\
\hline $\begin{array}{l}\text { Citrox } \\
\text { cc }\end{array}$ & $\begin{array}{l}0.3 \mathrm{M} \text { Oxalic Acid and } 0.2 \mathrm{M} \text { Citric Acid } \\
\text { cubic centimeter }\end{array}$ \\
\hline CFR & $\begin{array}{l}\text { cubic centimeter } \\
\text { Code of Federal Regulations }\end{array}$ \\
\hline $\mathrm{cm}$ & centimeter \\
\hline $\mathrm{cm}^{2}$ & square centimeter \\
\hline CRDL & Customer Required Detection Level \\
\hline DF & decontamination factor \\
\hline DOE & U.S. Department of Energy \\
\hline DOE/RL & U.S. Department of Energy, Richland Operations Office \\
\hline DOT & U.S. Department of Transportation \\
\hline DQO & data quality objective \\
\hline Ecology & Washington State Department of Ecology \\
\hline EPA & U.S. Environmental Protection Agency \\
\hline FGE & fissile gram equivalents \\
\hline FRG & Federal Republic of Germany \\
\hline$\stackrel{g}{\text { GEA }}$ & $\begin{array}{l}\text { gram } \\
\text { gamma energy analysis }\end{array}$ \\
\hline
\end{tabular}




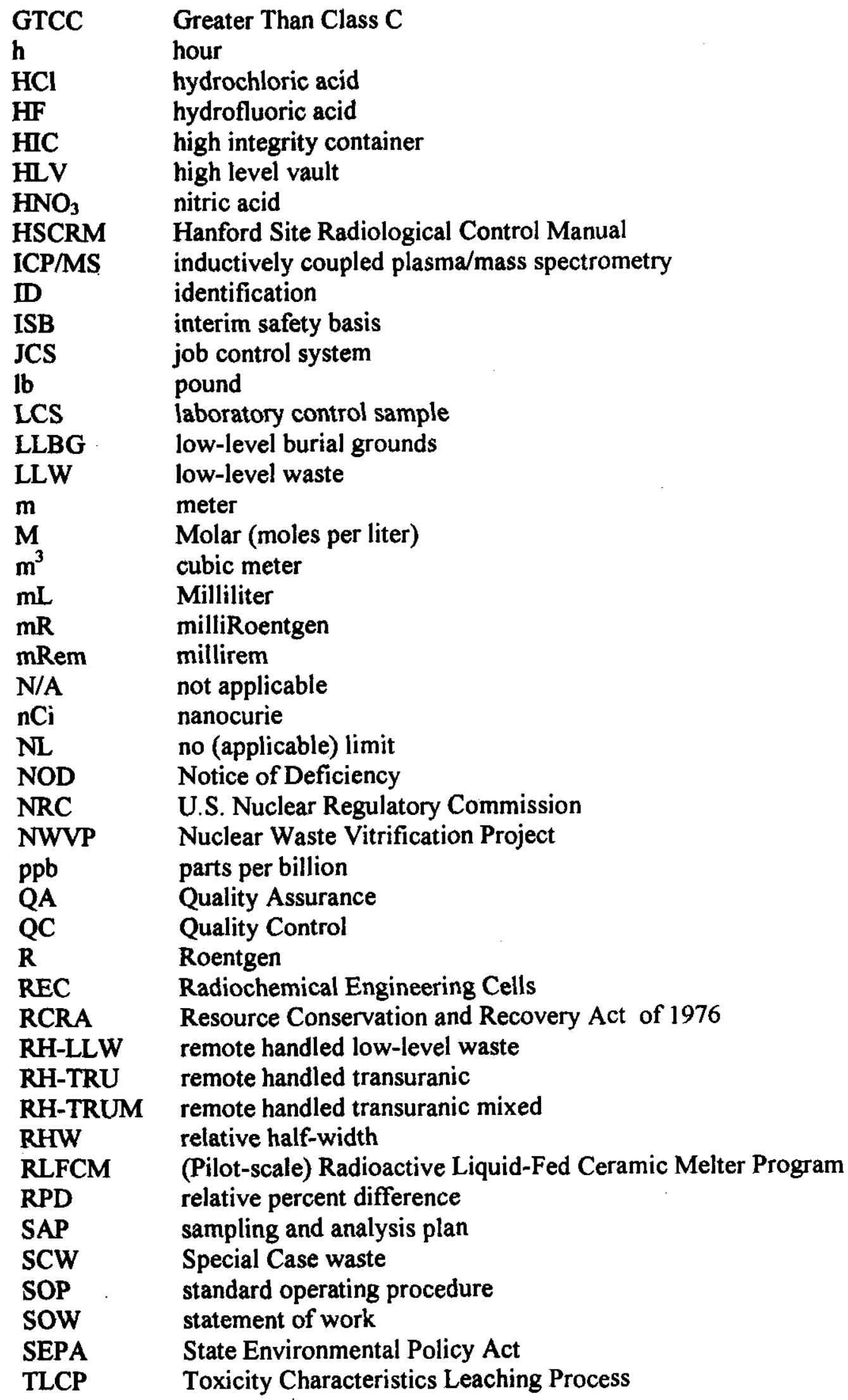


TPA

TRU

TRUM

TSD

TWD

TWP

$\mu \mathrm{Ci}$

WAC

WSEP

WIPP

WMH

WML

WMNW

ZVDP

Tri-Party Agreement (between DOE, EPA, and Ecology)

transuranic

transuranic mixed

treatment, storage, and/or disposal

technical work document

technical work plan

microcurie

waste acceptance criteria

Waste Solidification Engineering Prototype Program

Waste Isolation Pilot Plant

Waste Management Federal Services of Hanford, Inc.

Waste Management Laboratories

Waste Management Northwest, Inc.

Zeolite Vitrification Demonstration Project 


\section{B-CELL WASTE CLASSIFICATION SAMPLING AND ANALYSIS PLAN}

\subsection{INTRODUCTION}

The Hanford Site is operated by the U.S. Department of Energy, Richland Operations Office (DOE/RL). Hanford is located adjacent to and north of Richland, Washington. The 324 Facility is located within the 300 Area of the Hanford Site and is operated by Fluor Daniel Hanford, Inc. through a subcontract with B\&W Hanford Company (BWHC). Its purpose was to allow a high degree of versatility in completing complex and varied experimentation on highly radioactive wastes. Work within B-Cell (one of the Radiochemical Engineering Cells [REC] within 324 Facility) over the years included the Waste Solidification Engineering Prototype program (WSEP), the Nuclear Waste Vitrification Project (NWVP), the Zeolite Vitrification Demonstration Project (ZVDP), and the pilot-scale Radioactive Liquid-Fed Ceramic Melter (RLFCM) testing which included production of the Federal Republic of Germany (FRG) borosilicate glass logs (DOE/RL 1998a; Hobart 1998).

As a result of dispersed residues and internal facility spills during the conduct of these activities, the B-Cell hot cell contains areas of fixed and dispersible (i.e., easily spreadable) waste contamination. The floor dispersible material contains mixed waste (dangerous) waste contaminants (heavy metals). In the mid-1990's, it was determined that dangerous waste and waste residues were being stored for greater than 90 days in the 324 Facility REC (these areas are not Resource Conservation and Recovery Act of 1976 (RCRA) permitted portions of the 324 Facility). Through negotiations between U.S. Department of Energy (DOE), U.S. Environmental Protection Agency (EPA), and Washington State Department of Ecology (Ecology), it was agreed that a milestone would be added to the Tri-Party Agreement (TPA) for closure of nonpermitted mixed waste units within the 324 Facility and provided commitments to achieve the highest degree of compliance practicable, given the significant technical difficulties of managing mixed waste that contains high-activity radioactive materials and working remotely in areas within the hot cells (DOE/RL 1998a; Hobart 1998). B-Cell clean-out of both low-level waste (LLW) and mixed wastes is part of the TPA milestone.

The information obtained by this sampling and analysis plan (SAP) is required to support decision-making associated with waste classification and disposal of dunnage and sifted debris ${ }^{1}$ waste from B-Cell. The SAP fits into the B-Cell characterization document scheme as shown in Figure 1. It provides the mechanism by which statistically reliable and defensible data can be obtained to support development of a method of inferring the approximate levels of radionuclide constituents of a grout container loaded with B-Cell dunnage and sifted debris from measurements of the gamma dose rate from the ${ }^{137} \mathrm{Cs}$ constituent, which is easily measured.

\footnotetext{
' Sifted debris is considered items that have fallen to the cell floor and are later collected. The B-Cell floor dispersible material has been found to exhibit mixed (dangerous) waste characteristics (DOE/RL 1998a). All items having the potential for containing floor dispersible or tank heels are required by procedure to be rinsed of visible dispersible or heel material before being placed into the HN-200 grout container (DOE/RL 1998a; 3I-SOP-REC-A49).
} 
HNF-2804, Rev. 2

September 1999

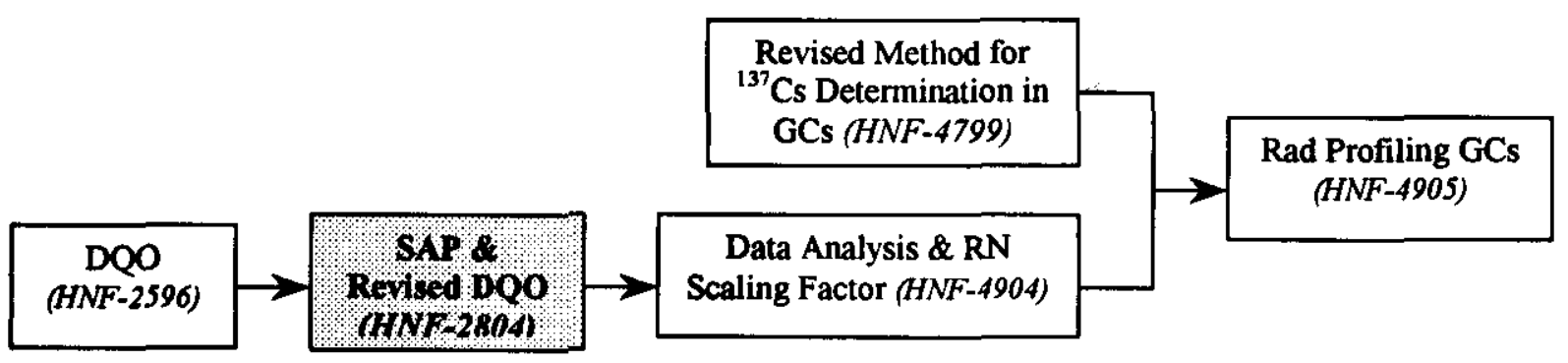

Figure 1. Overall B-Cell characterization document scheme

\subsection{Purpose}

This sampling and analysis plan defines the sampling and analytical methods that will be used to obtain samples to support the classification of the waste from B-Cell in the 324 Facility. The sampling and characterization of the B-Cell dunnage waste is required in order that the waste can be classified and accepted for disposal. The ability of sampling to produce quality samples is limited by system biases associated with waste heterogeneity and variability, sample capture bias, transport, and limited access due to availability of the structural material for sampling. The information on the radionuclide composition and spatial variability of the waste will be used to support programmatic decisions related to disposal of this waste.

This SAP consists of six sections:

- Section 1 provides the purpose, scope, and objectives (data quality, and sampling and analysis) of this sampling and analysis plan, as well as the historical background of B-Cell.

- Section 2 provides the sampling and analysis plan.

- Section 3 provides the quality assurance required for the sampling and analysis.

- Section 4 provides the tentative schedule for completion of the sampling and analysis.

- Section 5 provides references used in this sampling and analysis plan.

- Appendix A provides data quality objectives for this sampling and analysis plan that have been revised as new information is gained as issues reach closure.

\subsection{Scope}

The scope of this SAP is to establish the strategy and methods for collecting samples and compiling quantitative data on the radionuclide constituents present in dunnage waste generated during deactivation activities in B-Cell in the 324 Facility. Sampling and radioisotopic analysis will be performed on the fixed layer of contamination present on structural material and process tanks or vessels. Additionally, samples will be collected to support studies of potential decontamination methods that are effective in removing the fixed contamination present on the waste. 
HNF-2804, Rev. 2

September 1999

This SAP addresses only radionuclide characterization related to metal dunnage waste generated during deactivation activities in B-Cell. Issues related to the classification of this waste as non-dangerous waste (i.e., not mixed waste) have been discussed elsewhere (Shelor 1999, Rasmussen 1999a-1999h). This SAP does not address other issues associated with closure of B-Cell.

\subsection{Data Quality}

The objectives and goals for this study were originally defined in HNF-2596, Data Quality Objectives for the B-Cell Waste Stream Classification Sampling (Barnett 1998). A formal Data Quality Objective (DQO) process was not performed or required, but elements of the DQO process, such as data quality analysis, are incorporated as appropriate. Since publication of the DQO document, further iterations of the data quality process have resulted in updates of the objectives and further definitions of the objectives of this study. The revised data quality process for the fixed contamination layer characterization study after the initial analyses on the $1 \mathrm{~B}$ rack samples and the first batch of $1 \mathrm{~A} / 2 \mathrm{~B}$ samples is summarized in Appendix A.

\subsection{Sampling and Analysis Objective}

The objective of the sampling and analysis activities is to provide radionuclide characterization data on the fixed contamination layer of metal structures to support decisions related to classifying the B-Cell wastes to meet Hanford solid waste acceptance criteria as defined in HNF-EP-0063, Rev. 5 (WMH 1998).

The radionuclides of concern for this SAP are ${ }^{137} \mathrm{Cs},{ }^{90} \mathrm{Sr}$, and transuranic radionuclides (such as ${ }^{239 / 240} \mathrm{Pu},{ }^{238} \mathrm{Pu},{ }^{241} \mathrm{Am}$, and ${ }^{244} \mathrm{Cm}$ ) based on previous data on B-Cell constituents (Webb 1997; Durham 1998). Analysis for other radionuclides may be performed if the stated radioassays fail to identify all alpha-emitting radionuclides present in the fixed layer of the metal samples.

\subsection{B-Cell Description and Background}

Historical operations in the 324 Facility B-Cell between 1965 and 1992 have generated a large volume of legacy radioactive waste. The B-Cell activities are summarized in Table 1. During these operations, approximately 70 million of curies of radioactive material, primarily ${ }^{137} \mathrm{Cs}$ (and ${ }^{137 \mathrm{~m}} \mathrm{Ba}$ ) and ${ }^{90} \mathrm{Sr}$ (and ${ }^{90} \mathrm{Y}$ ), were processed in B-Cell. It is estimated that thousands of $\mathrm{Ci}$ of radioactive contamination, both in dispersible and fixed form, reside in B-Cell (Greenborg 1999). 
Table 1. Chronology of B-Cell Activities

\begin{tabular}{|c|c|}
\hline a & Butes \\
\hline - Waste Solidification Engineering Prototype Program (WSEP) & $1966-1972$ \\
\hline - No Activity * & $1972-1976$ \\
\hline - Nuclear Waste Vitrification Project (NWVP) & 1976-1979 \\
\hline - No Activity* & $1979-1981$ \\
\hline - Zeolite Vitrification Demonstration Project (ZVP) & 1981 \\
\hline $\begin{array}{l}\text { Pilot-scale Radioactive Liquid-Fed Ceramic Melter } \\
\text { (RLFCM) testing task (includes cell prep and installation of } \\
\text { RLFCM equipment) }\end{array}$ & $1982-1986$ \\
\hline $\begin{array}{l}\text { - Federal Republic of Germany (FRG) Program (production of } \\
\text { isotopic heat sources) }\end{array}$ & 1986-1987 \\
\hline - No Activity* & $1987-1988$ \\
\hline - B-Cell Cleanout & 1988-present \\
\hline
\end{tabular}

* Periods listed as 'no activity' indicate that no project or R\&D activities were occurring in the cell during that time.

Cleanup activities to date have removed several vessels and racks, including the 1-B rack, from B-Cell and have allowed removal of dispersible mixed waste from approximately $80 \%$ of the floor area. The material in B-Cell that must be removed to allow access to the remaining floor area consists of two equipment racks: 1-A, and 2-A. These racks contain structural material, process piping, and vessels. From information gained from engineered drawings (see $\mathrm{H} 3-21000$ ), it appears that the majority of the metal material is 304L stainless steel alloy. Some tanks are titanium.

A B-Cell waste package consists of a $\mathrm{HN}-200$ grout container containing the waste and grout (to reduce residual, removable contamination, to fill void spaces, and to lower the external dose rate) and a liner that reduces the amount of contamination introduced into the shipping cask from the grout container. A waste package is generated by sizereducing the stainless steel racks or vessels, placing the rack material into grout containers, adding grout to the containers, loading the grout container into a liner in a relatively low-contamination area (the REC Airlock), loading the liner into an 3-82B shipping cask, and shipping the sealed cask to the Hanford burial grounds. The dose rates at the surface of waste packages originating from B-Cell are sufficiently high that they must be handled remotely. Thus, all waste from B-Cell is remote handled. The term remote handled is not a waste classification, but rather it is a descriptor that indicates how it is to be handled and stored.

Designation of B-Cell waste to date has previously relied on process knowledge and limited data on the removable contamination on the structural material.

In 1997, the basis for shipping B-Cell waste to the Hanford burial grounds was reviewed. During the review, it was discovered that the waste classification used at the time was based on three smear samples obtained from rinsed surfaces of B-Cell waste in 1993. 
HNF-2804, Rev. 2

September 1999

These samples, representing the removable contamination present, were used to establish the ratio of ${ }^{90} \mathrm{Sr}$ to ${ }^{137} \mathrm{Cs}$. The alpha content of waste shipped from B-Cell to the Hanford burial grounds prior to 1997 was not explicitly determined.

Upon review of the existing procedure for shipping waste to the burial grounds, a programmatic decision was made to obtain additional smear data. Three additional smears were obtained for rinsed surfaces of non-waste material in B-Cell in 1998. The results of the six smears are summarized in Table 2.

Table 2. Summary of Smear Data Used in Previous Technical Basis for Shipping B-Cell Waste*

\begin{tabular}{|c|c|c|c|c|}
\hline Kople & 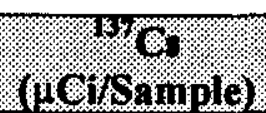 & 19(1) & ( & 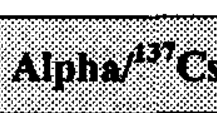 \\
\hline 1993-1 & 0.135 & 0.365 & 0.0000592 & 0.000439 \\
\hline 1993-2 & 0.0505 & 0.113 & 0.0000229 & 0.000453 \\
\hline 1993-3 & 0.0437 & 0.074 & 0.0000229 & 0.0000524 \\
\hline 1998-1 & 0.00973 & 0.00128 & 0.0000545 & 0.00560 \\
\hline 1998-2 & 0.229 & 0.0769 & 0.00010 & 0.000437 \\
\hline 1998-3 & 8.93 & 0.622 & 0.00365 & 0.000409 \\
\hline
\end{tabular}

After analyzing the data, a revised technical basis (Shelor 1999) was established for characterizing grout containers (Durham 1998). According to the new basis, the radionuclide content of the grout containers was determined in the following manner:

- A dose profile was obtained by taking the dose rate at 24 locations around a grout container.

- The 24 dose rate measurements were averaged.

- The ${ }^{137} \mathrm{Cs}$ content was estimated using the developed conversion factor of 0.219 $\mathrm{R} / \mathrm{hr} / \mathrm{Ci}$.

- The heat generation and waste classification were determined by applying radionuclide scaling factors, such as a $2.57: 1{ }^{90} \mathrm{Sr} /{ }^{137} \mathrm{Cs}$ ratio and a 0.000408 alpha $/{ }^{\mathbf{1 3 7}} \mathrm{Cs}$ ratio (Shelor 1999).

The criteria used for waste classification determination of a grout container were the following (Shelor 1999):

- The alpha $/{ }^{137} \mathrm{Cs}$ ratio must be less than $100 \mathrm{nCi} / \mathrm{g}$ to be designated as Category 3 waste.

- The alpha $/{ }^{137} \mathrm{Cs}$ ratio must be less than $135 \mathrm{nCi} / \mathrm{g}$ to be designated as LLW (assuming that $84 \%$ of alpha activity is non-TRU since ${ }^{244} \mathrm{Cm}$, which is non-TRU, is included in the total alpha activity).

- The heat generation rate must be less than 60 watts and was based on ${ }^{90} \mathrm{Sr}$ and ${ }^{137} \mathrm{Cs}$ activities. The heat generation rates used were 0.0067 watt $/ \mathrm{Ci}^{90} \mathrm{Sr}$ and 0.0048 watt/Ci ${ }^{137} \mathrm{Cs}$ (Shelor 1999). 
- To meet the dose rate limits of $200 \mathrm{mrem} / \mathrm{hr}$ at the cask surface and $10 \mathrm{mrem} / \mathrm{hr}$ at 2 $\mathrm{m}$, it was determined from an earlier study (WMNW, 1998) that, 3,600 Ci of ${ }^{137} \mathrm{Cs}$ and 7,560 $\mathrm{Ci}$ of ${ }^{90} \mathrm{Sr}$ would meet the dose rate limits assuming that the 3-82B shipping cask is loaded with a $2.1: 1$ ratio of ${ }^{90} \mathrm{Sr}$ to ${ }^{137} \mathrm{Cs}$ (Shelor 1999).

A review of the B-cell cleanout waste stream classification by $B \& W$ Hanford Company determined that worst-case waste packages generated by the program might fall outside the LLW limits with respect to TRU content. The current method for designating B-Cell waste is based on analytical characterization of residual removable contamination on rinsed surfaces of B-Cell. However, process knowledge indicates that most of the contamination in B-Cell is fixed and that the isotopic distribution of radionuclides in the fixed layers may be significantly different from that of the residual removable contamination. Additionally, process knowledge indicates that the fixed contamination is likely to contain less alpha contamination than the removable contamination. Demonstration of this indication would allow much of the waste in B-Cell to be designated as low-level waste (LLW).

In the past, process knowledge of the origin of radionuclide contamination present in the B-Cell waste stream was deemed sufficient to allow classification of metal waste being removed from the cell as low-level waste, as long as the removable contamination was rinsed off the waste. It was assumed that the fixed contamination present on material in the cell was a product of a melter off-gas release, and contained the same mixtures of isotopes $\left({ }^{90} \mathrm{Sr}\right.$ and $\left.{ }^{137} \mathrm{Cs}\right)$ that was present in the melter at the time of release. Similarly, it was assumed that rinses of process equipment performed after processing removed the majority of process solution residuals from piping and vessels. No documentation can be found that specifically verifies these conditions.

The contamination present in the B-Cell waste stream originates from three distinct sources (Figure 2):

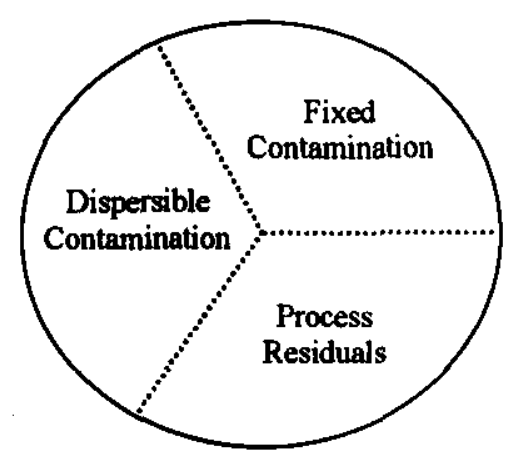

Figure 2. Contributions to the Measured Dose Rate of B-Cell Waste In Grout

- Process residuals present inside piping and vessels involved in past engineering processes. This waste stream will be discarded as remote-handled transuranic mixed waste (RH-TRUM). 
- Dispersible contamination present in the cell from process upsets and spills. This material is deposited on the waste during the course of normal cell operations, but the majority of this material can be removed from the waste by a pressurized water rinse.

- A fixed layer of material that is present on exposed metal surfaces in the cell. This fixed layer is known to exist based on observed dose rates on containers of rinsed waste comprised only of structural materials from the racks (rack legs and structural support members that were not directly exposed to process solutions) ranging from 10 $\mathrm{R} / \mathrm{hr}$ to $1,000 \mathrm{R} / \mathrm{hr}$. This fixed layer is thought to have originated from plating of volatilized materials released from the radioactive liquid-fed ceramic melter during production of the FRG glass logs.

Although analytical information of radionuclides present in process solutions used as feedstock during vitrification projects is available, no radionuclide characterization of fixed contamination present on external surfaces of the equipment racks or process vessels had been obtained as of October 1998. Also, no radionuclide characterization of process residuals present as fixed contamination inside auxiliary vessels has been performed. Radioanalytical information from smears of removable contamination present in the cell is the only direct information currently available to estimate the radionuclide makeup of grout containers from external dose rates.

Data on the radionuclide content of removable and fixed on metal surfaces in the waste stream must be collected to validate the classifications of the B-Cell waste stream as LLW, Greater-than-Category C waste, or TRU waste. This information will be used to establish the relationship between ${ }^{137} \mathrm{Cs}$, which will be used as a tracer radionuclide, and the alpha-emitting radionuclides present in the waste stream. This relationship will be used to determine the alpha content of individual waste packages generated from this waste stream.

The methodology previously used to determine the radionuclide content of loaded grout containers and to designate the waste removed from B-Cell is shown schematically in Figure 3. The contribution from dispersible contamination is minimized by rinsing the waste material before it is placed into the grout containers (Shelor 1999, Rasmussen 1999a-1999h). This methodology is in the process of being revised and refined to incorporate new information gained from the analytical results.

The bottom portions of the process vessels were segregated and discarded as remotehandled transuranic (TRU) waste, thus minimizing the contribution from these items in the waste packaged in the grout containers. Dose rate profiles of containers were routinely obtained before and after grouting the waste. The average dose rate at the surface of the container was calculated from the grouted dose rate profiles. The primary gamma dose contributor in the waste stream is known through process history and existing analytical data to be ${ }^{137} \mathrm{Cs}$. Prior to this work, computer modeling was used to estimate the amount of ${ }^{137} \mathrm{Cs}$ necessary to generate the observed average dose rate of the container. This information was then used to estimate the amounts of other radionuclides present in the waste by multiplying the ${ }^{137} \mathrm{Cs}$ content by the ratio of TRU activity to ${ }^{137} \mathrm{Cs}$ activity. 
HNF-2804, Rev. 2

September 1999

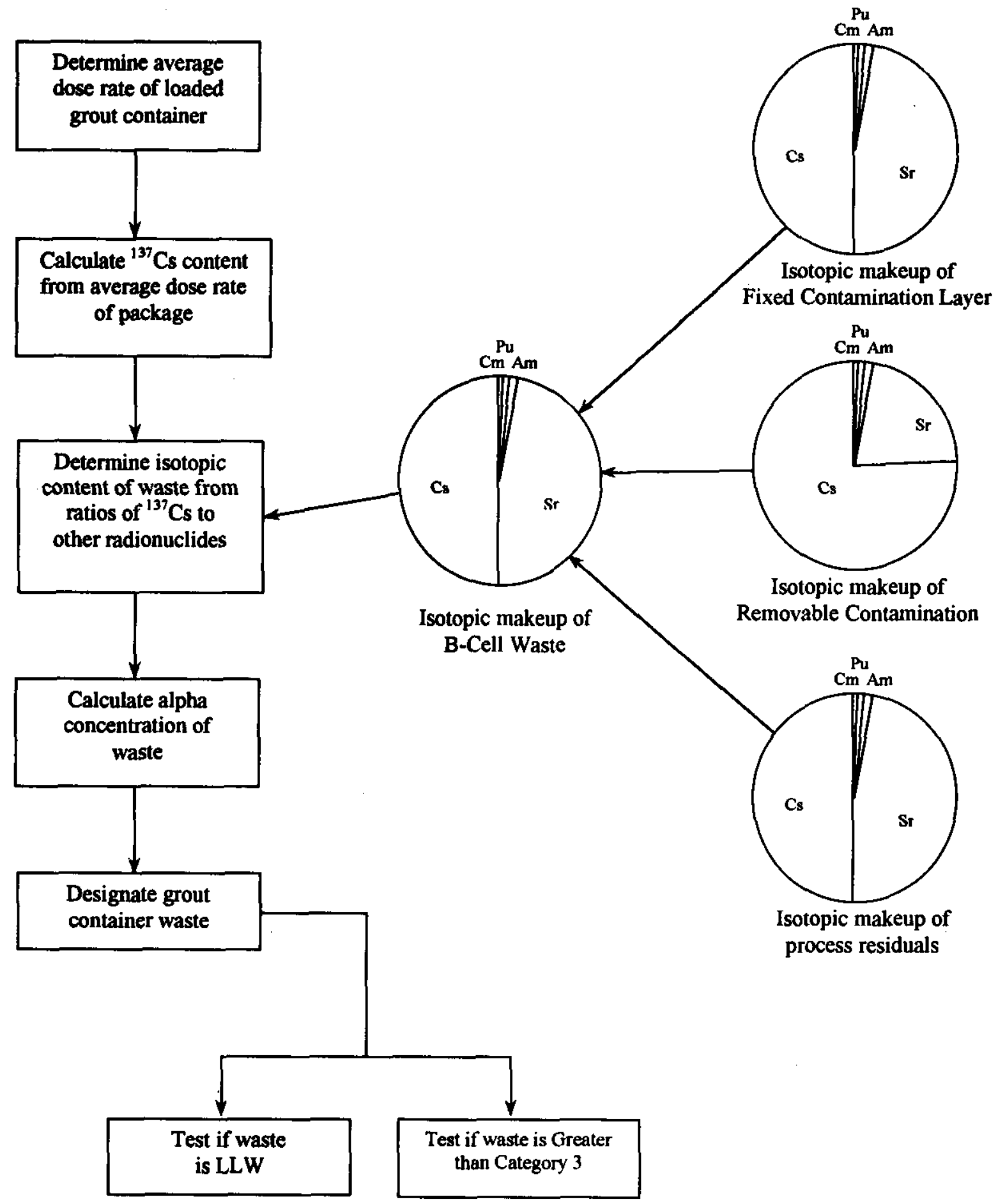

Figure 3. General Methodology Used to Calculate Isotopic Content of B-Cell Loaded Grout Containers 
HNF-2804, Rev. 2

September 1999

The alpha: ${ }^{137} \mathrm{Cs}$ ratio that was applied to B-Cell waste was determined through the analysis of six smears (see Table 2) taken from rinsed surfaces in B-Cell (Shelor 1999). The waste classifications for the grout containers were made from this data.

\subsection{SAMPLING AND ANALYSIS PLAN}

\subsection{Scope of Work}

The scope of the SAP is to accomplish sampling and analysis of rack and vessel metal dunnage that are to be removed from B-Cell as defined in the revised data quality process (Appendix A). The objective of this study is to assess the radionuclide concentrations in the fixed contamination layer on the dunnage to support decision-making regarding its disposal.

As a result of budgetary and schedule constraints, the workscope for this study is limited and has been prioritized to optimize the data collected. Sampling will be performed in three phases. Rack 1B will be sampled first. Rack 1A and associated vessels and tanks will be sampled next. And, the $2 \mathrm{~A} / 2 \mathrm{~B}$ racks will be sampled last. This sampling priority was selected to coincide with the overall schedule for reduction and removal of the racks from the hot cell. Sampling may be curtailed if statistical analysis demonstrates that the fixed contamination layer on the metal dunnage is characterized to the degree specified in the revised data quality document (Appendix A).

\subsection{General Requirements}

The regulatory guidance is that provided in HNF-EP-0063, Rev. 5, Hanford Site Solid Waste Acceptance Criteria (WMH 1998), and the Safety Analysis Report for the 3-82B cask (SEG 1991). The goal is to ship the B-Cell waste in grout containers as low-level waste.

To properly classify the waste and to comply with the waste acceptance criteria (WMH 1998), the concentration of each major radionuclide has to be established. According to HNF-EP-0063 (WMH 1998), major radionuclides are those that meet any of the following conditions:

- Any TRU radionuclide present in the waste in concentration exceeding $1 \mathrm{nCi}$ per gram.

- Any fissionable radionuclide present in concentration exceeding greater that $0.1 \%$ fissile gram equivalent (FGE).

- Any radionuclide that accounts for more than $1 \%$ of the total radioactivity of the waste.

- Any radionuclide present in concentration exceeding $1 \%$ of its respective Category 1 limit.

- Mobile radionuclide present in concentration greater than its reporting limit. 
HNF-2804, Rev. 2

September 1999

The following characterization methods may be used to establish the radionuclide inventory (WMH 1998):

- Process knowledge

- Radionuclide material accountability

- Direct measurement methods

- Computer modeling

- Scaling factors

- Other methods that are clearly documented and approved.

The specific criteria that apply to grout container transport and disposal are as follows:

- Transuranic (TRU) Limit - The TRU content must not exceed $100 \mathrm{nCi}$ per gram of waste (DOE Order 5820.2A as stated in HNF-EP-0063).

- Category 3 Limit - Waste category must not exceed Category 3 (HNF-EP-0063).

- Heat Generation Limit - The heat generation from radioactive decay in the waste package must not exceed 3.5 watts per $\mathrm{m}^{3}$, otherwise an evaluation of the waste package is necessary to ensure the heat does not affect the integrity of the container or surrounding containers in the LLBG. The 3-82B shipping cask is limited to 205 BTU/hr or 60 watts (SEG, 1991); ${ }^{2}$ NRC 1997; MMT 1998).

- Dose Rate Limits - Remote-handled waste must not exceed $200 \mathrm{mrem} / \mathrm{hr}$ at contact with the cask surface or $10 \mathrm{mrem} / \mathrm{hr}$ at $2 \mathrm{~m}$ from the cask surface in order to meet the DOT shipping regulations (DOT 1999: 49 CFR Parts 100 to 185).

\subsection{Sample Location and Frequency}

The source of the waste stream being examined is process equipment racks present in B-Cell. The racks consist of tanks and vessels, and process and utility piping that is contained inside a structural support. All of the rack components are metal. Process history was used to determine the populations present on the racks that may require sampling. The following assumptions, based on process history, were considered pertinent to establishing sample populations:

- All external surfaces present on the rack were coated with 'fixed' contamination during a 1985 melter off-gas release to the cell including both process and structural equipment.

- Rinsing of auxiliary vessels such as de-misters, condensers, off-gas heaters, and condensate collection tanks in the racks was done both before and after any process work was completed. This means that they are relatively clean internally and contain minimal internal residual process deposits. It is anticipated that a layer of fixed contamination will be present outside of the process piping and auxiliary vessels similar to structural surfaces. Much of the internal surface should be free of process residue due to post-run flushing. Primary tanks in the equipment racks may contain process sludge in the lower portions that cannot be readily removed from the tanks and are likely to contain hazardous constituents, making them mixed waste. This condition will require handling these portions of the primary tanks as Special Case

\footnotetext{
${ }^{2}$ The conversion factor used is 3.414 BTU/watt-hr (SEG 1991).
} 
HNF-2804, Rev. 2

September 1999

Waste, so they can be excluded from this waste stream. For more information on disposition of primary tanks, see HNF-1730, Rev. 1, 324/327 Buildings Special Case Waste Assessment and Disposition Alternatives Analysis, March 1998.

- Due to the complexity and cost of sampling and analyzing process piping, a programmatic decision was made not to include piping in this SAP. Rather, rack piping will be disposed of as transuranic mixed (TRUM) waste as a conservative measure.

- The rack disassembly is a complex procedure and provides manipulator access only to limited areas of the rack at any one time. Because of the access limitation it was decided to sample during the normal cutting process and load out the samples in small batches for shipment to the 222S Laboratory (henceforth referred to in this SAP as the "Laboratory"). An example of this approach is as follows. The 1A rack will be sectioned into an upper portion and a lower portion. After severing the rack at the fractionator tower and immediately above the middle structure horizontals, the upper portion will be size reduced in two stages. First, the two condensers and fractionator tower will be cut into pieces. Then the structure will be cut into pieces and packaged. During this time period, samples of the vessels may be obtained followed by rack structure samples once the weight of the vessels has been removed. Uniquely identified samples from known rack locations are to be placed in pre-labeled closed metal containers as they are taken. When the cell access is open they are to be moved to the airlock for loadout/prompt shipping. The analysis will proceed while other cutting occurs.

Any surfaces with visible residual will be segregated and characterized as mixed waste, not LLW.

The technical basis for obtaining samples for analysis in B-Cell is contained in Statistically Based Sampling of Pipes, Tanks, and Racks in B-Cell (Jensen and Wilmarth, 1998). The recommendations, based on data existing at that time (smears of removable contamination within B-Cell), are the following:

- Locations of sampling be chosen at random in order that the results may be applied to the entire population of waste

- Duplicate samples are suggested

- A minimum of 15 sampling locations will be needed to keep the relative half-width (RHW) of the statistical confidence interval (CI) to approximately $50 \%$. The RHW, expressed as a percentage of the mean, is used to determine how the width of the CI decreases as the number of sampling locations increases.

Seven samples were randomly obtained from Rack 1B from the connector nozzle array. Of these, four samples were sent to the Laboratory for subsectioning and analysis. The subsections of each sample were labeled "A" and "B", but were treated as discrete samples. Additional samples were taken from Racks 1A (21 samples), 2A (17 samples), and $2 \mathrm{~B}$ ( 2 samples), and the upper portions of their associated tanks and vessels as they become available for sample cutting. Facility engineering and operations staff have specified the randomly selected sampling locations displayed in Figures 4 and 5 . If additional data are required to meet the conditions of the revised data quality document (Appendix A), additional samples will be collected and processed. 
HNF-2804, Rev. 2

September 1999

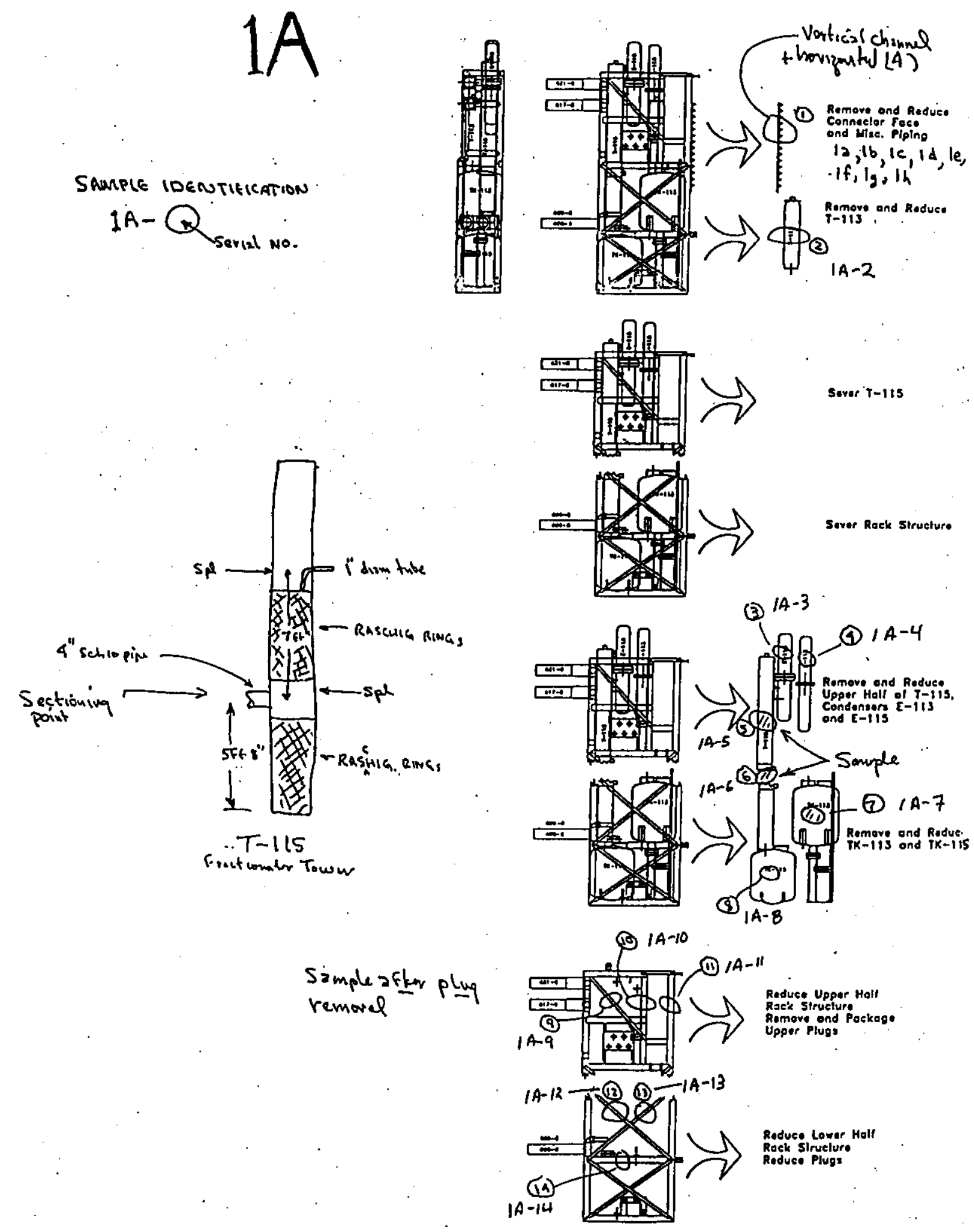

Figure 4. Sample Locations on the IA Rack 

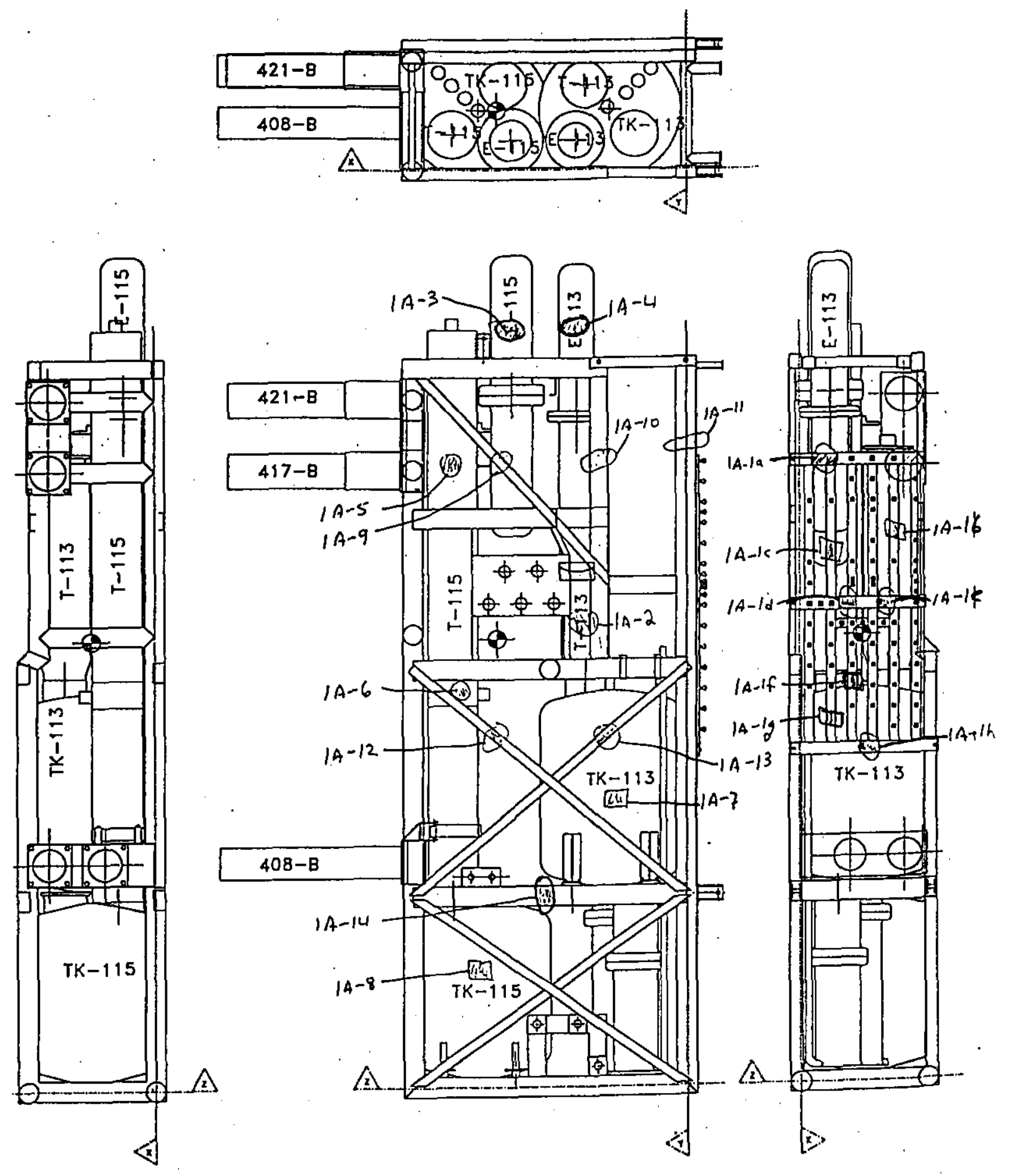

Figure 4. Sample Locations on the IA Rack (continued) 


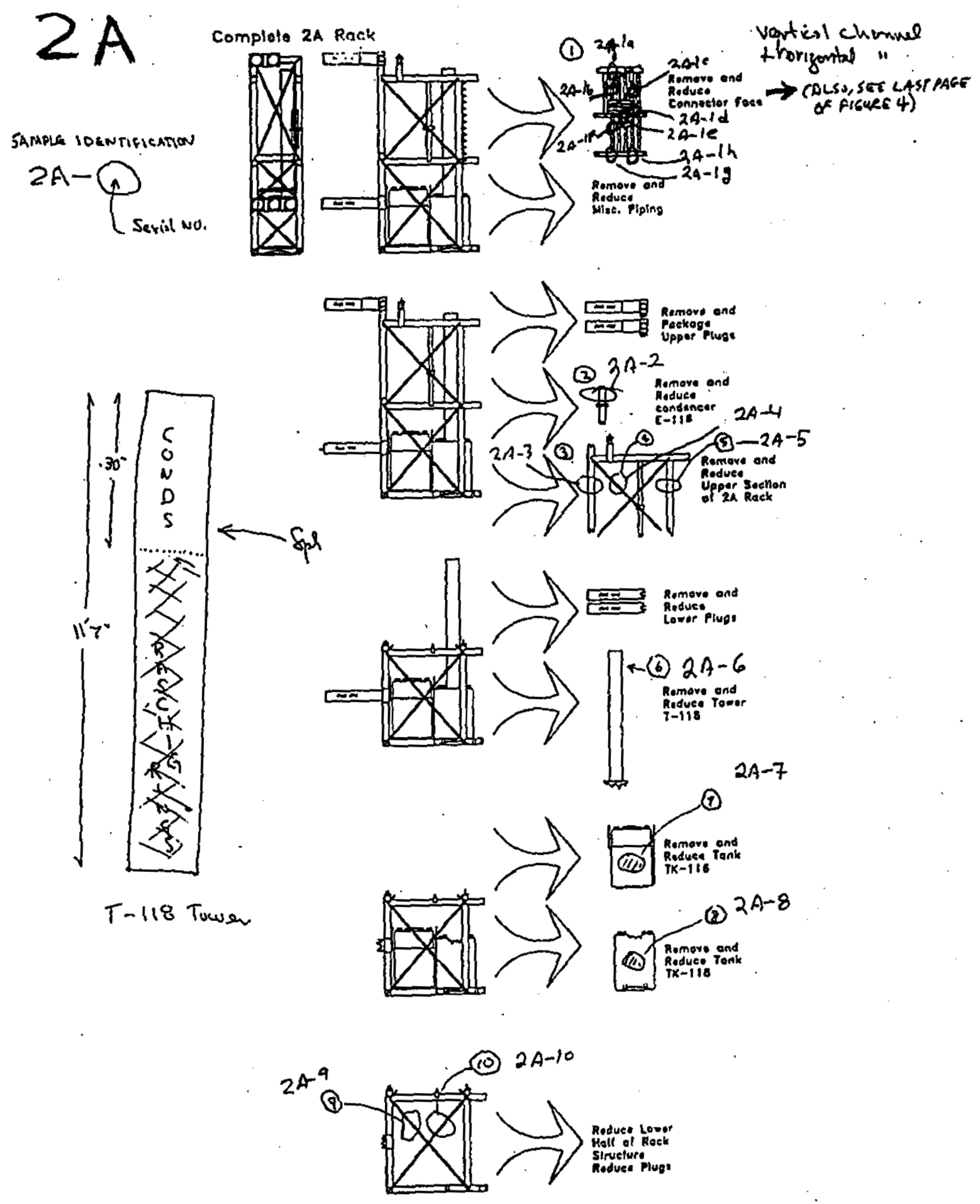

Figure 5. Sample Locations on the 2A Rack 
HNF-2804, Rev. 2

September 1999

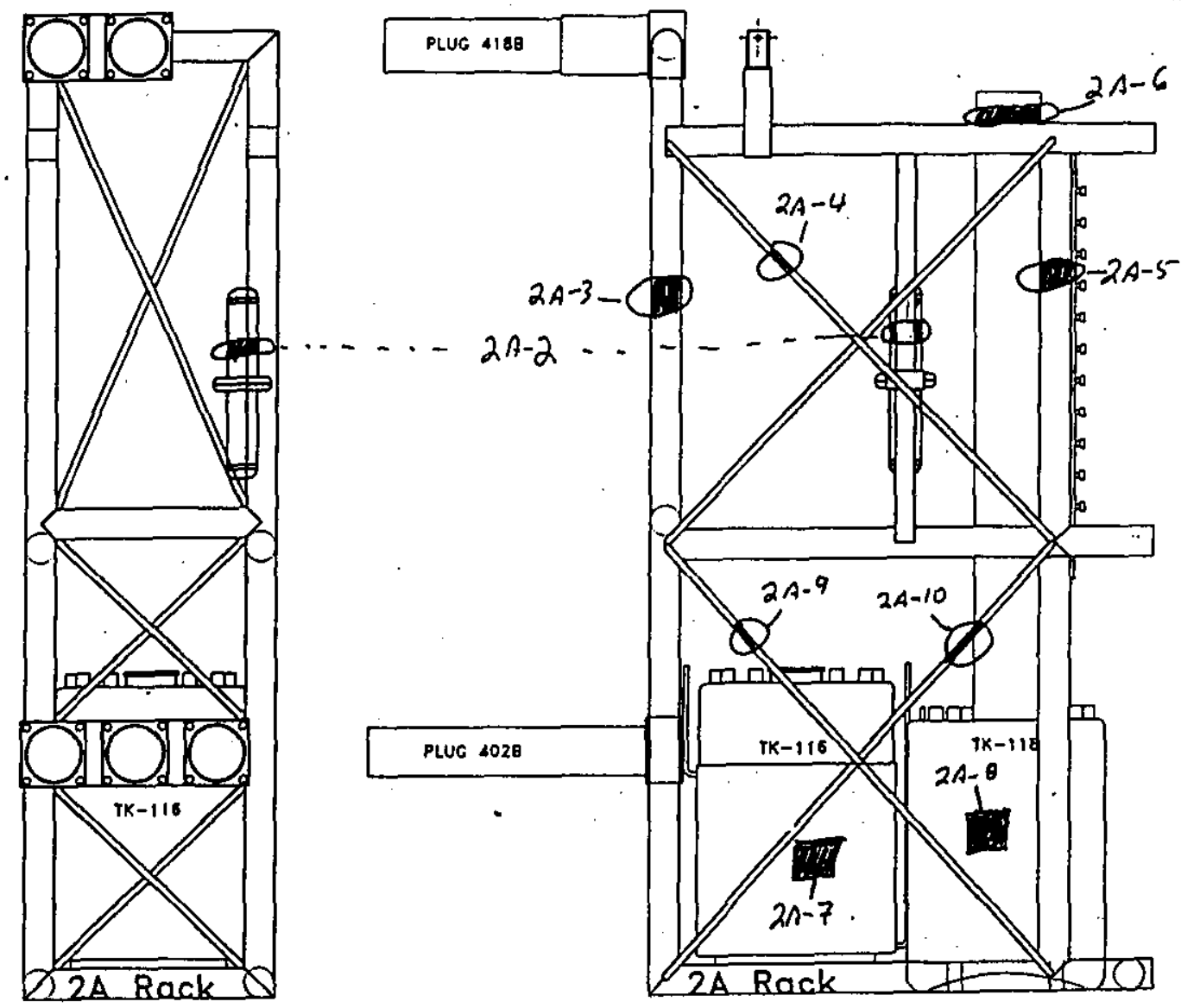

Figure 5. Sample Locations on the 2A Rack (continued) 
HNF-2804, Rev. 2

September 1999

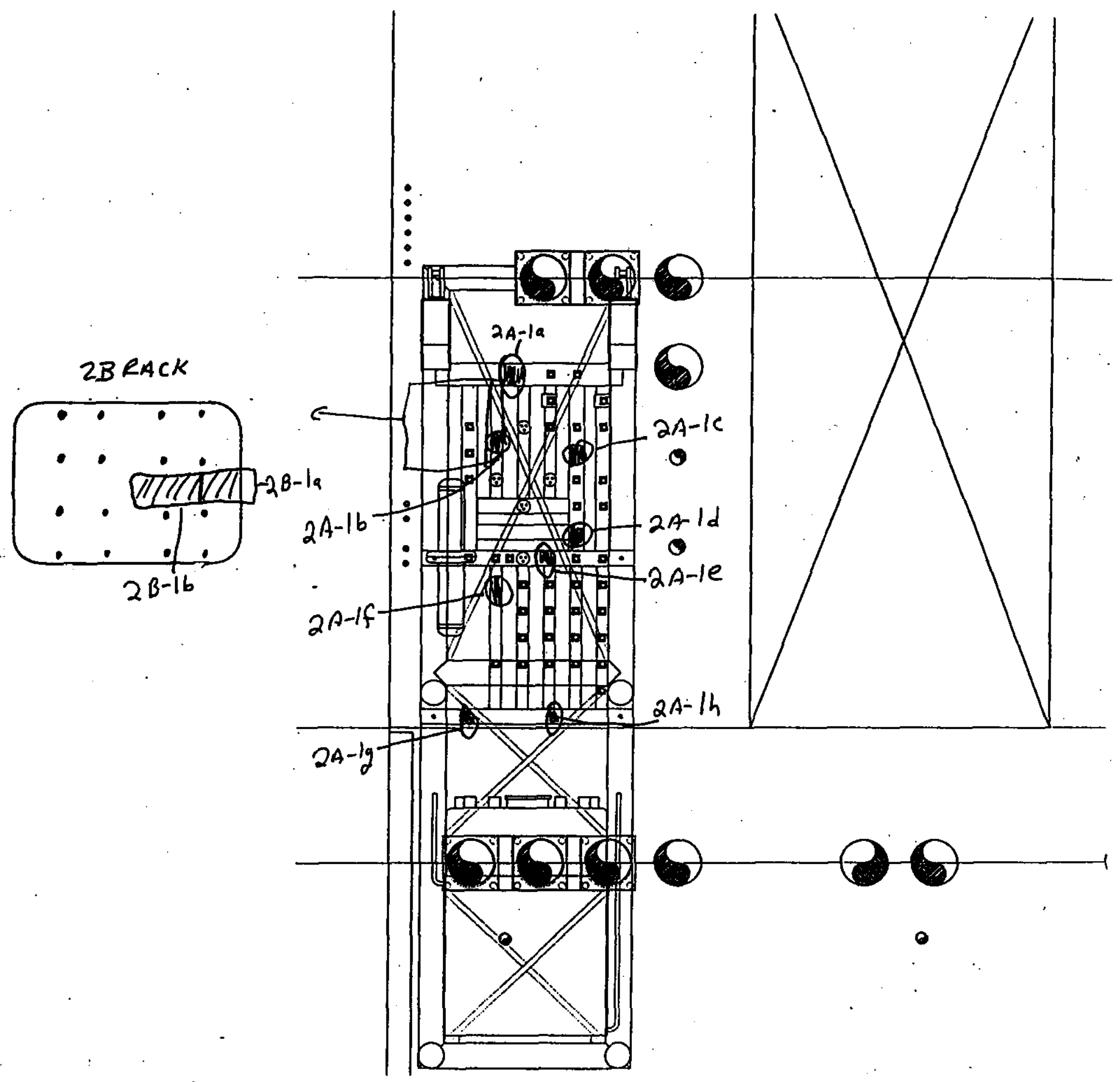

Figure 5. Sample Locations on the 2A Rack (continued) 


\subsection{Sample Designation, Handling and Custody}

Exact sample locations, ID numbers for each sample, and pertinent remarks (such as unusual circumstances, visualization of crusty material on the surface, etc.) will be recorded on a data sheet that will be included in the job control system (JCS) packages/work plans generated to control this work. The sample ID information will be supplied to the Laboratory upon shipment.

Custody and handling of the sample until they reach the Laboratory will be performed in accordance with guidelines and requirements set forth in Section 6.1, Waste Generation Management Plan, in 324/327 Facilities Stabilization Projects Administrative Manual (HNF-IP-1264).

\subsection{Sample Collection and Analysis}

The operating procedures and technical work plans (TWPs) listed in Table 3 are scheduled to be used by the 324 facility personnel to collect the samples and prepare them for shipping to the 222S Laboratory.

Table 3. Operating Procedures and Technical Work Documents for Sampling and Handling of B-Cell Metal Rack Samples

\begin{tabular}{|l|l|}
\hline 3ROCABUI & \\
\hline 3I-98-0051/W & Size Reduce 1B Rack * \\
\hline 3I-TWP-98-019 & 2A Rack Removal \\
\hline 3I-TWP-98-021 & 2A Rack Size Reduction \\
\hline 3I-TWP-98-026 & Partial Disassembly of the 1A Rack, B Cell \\
\hline 3I-TWP-98-030 & 1A Rack Size Reduction - Phase II \\
\hline 3I-TWP-98-035 & Racks 1A, 2A, \& 2B Waste Characterization Sampling Plan \\
\hline 3I-TWP-98-044 & Receiving and Shipping Instructions for the 3-82B Cask \\
\hline 3I-SOP-REC-A-42 & 3-82B Cask Low Level Waste (LLW) Loading \\
\hline 3I-SOP-REC-A-49 & Preparing/Loading Low Level Waste (LLW) Grout Container \\
\hline 3I-SOP-REC-K-22 & In Cell Operation of Thermal Arc Plasma Cutting System \\
\hline $\begin{array}{l}\text { WHC-SD-TP- } \\
\text { OMM-002 }\end{array}$ & $\begin{array}{l}\text { Operating and Maintenance Instructions for the Hedgehog Sample } \\
\text { Package (A DOT 7A Type A Package) }\end{array}$ \\
\hline $\begin{array}{l}\text { Section 6.1 in } \\
\text { HNF-IP-1264 }\end{array}$ & $\begin{array}{l}\text { Waste Generation Management Plan in 324/327 Facilities } \\
\text { Stabilization Projects Administrative Manual }\end{array}$ \\
\hline
\end{tabular}

* Note that, due to an administrative error, the TWP for size reducing the 1B Rack did not include collection of samples per this SAP. However, seven samples from the connector nozzle array of this rack were collected prior to the waste being removed from B-Cell.

Originally, the samples were planned to be cut by 324 facility personnel using plasma arc torch or by hole saw. However, only the plasma arc torch was used since the hole saw 
was found not to be feasible for this work. When samples are cut by a plasma torch, the samples are to be large enough to leave 3 to 4 square inches of non-heat affected surface area. Note that the heat-effected areas are not usable for analysis. Refer to Figures 4 and 5 for sample locations on Racks 1A, 2A, and 2B. When a process vessel is sampled and the outer diameter is greater than 12 inches, then the outer wall must be marked.

Sample locations of each piece with pertinent remarks, such as variation from the indicated sample locations, will be recorded on a Sample Log Data Sheet, in accordance with the 3ITWP-98-035 technical work plan, and will be included in the JCS package/work plan generated to control this work. When a piece is cut, it will be stored in a closed container (prelabeled). The container will be moved to the REC Airlock, when possible, where samples will be cut to more manageable size, packaged and loaded out. The Hedgehog shipping cask will be used. All samples will be shipped to the Laboratory to be available for analyses, as needed.

The general criteria for laboratory preparation and handling initially proposed were the following. Note that some of these guidelines were changed as lessons learned were gained. Changes were captured in the reports from the Laboratory.

- The potential for cross-contamination of the edges of the samples from handling and cutting should be minimized.

- Both the removable film and the tightly adherent, fixed radioactive layer on both sides of the metal specimen will be determined. If the metal specimen is from a vessel wall, analyze the inner and outer surfaces separately.

- The existing 1B samples were too large for lab work. The initial samples were cut into multiple specimens. Two specimens from each sample were segregated into a specimen set for waste characterization study (duplicates). Remaining specimens from each sample were saved for the fixed contamination layer removal studies.

- Samples from tanks and vessels will be further subdivided for analysis of the exterior versus interior surfaces.

- Obtain and submit a photograph of each specimen, with a millimeter ruler in each frame.

- Obtain and submit data from radiation measurement of the specimen before and after the analytical process.

- Obtain and submit data of measurement of the total surface area of surfaces that underwent the analytical process.

Specific actions required of the analytical Laboratory for characterizing the fixed contamination layer on the rack/vessel metal samples are given below. Additional requirements or changes to the listed specific actions will be incorporated into the statement of work (SOW) that is to accompany each batch of metal samples sent to the Laboratory for analysis. It should be noted that, for major subcontractors to Fluor Daniel Hanford, Inc., the contractual analytical laboratory for high-activity sample analyses is the 222S Laboratory.

- Because the specimens will potentially be contaminated from handling, the extraneous material (or removable portion) is to be removed and analyzed in addition 
to the analysis done on the remaining fixed contamination layer. The recommended approach is to ultrasonically clean the specimen to remove the easily removable contamination on both the edges and on surface of the specimens using demineralized water. At this stage, the edges are to be coated with a masking agent to prepare the specimen prior to removal of the fixed contamination layer. Alternately, a moderately concentrated nitric-hydrochloric acid (with a swab) could be used to clean the edges if the effectiveness can be demonstrated. Possible masking agents include hard paraffin wax or electroplating stop-off lacquer (microshield or equivalent) or epoxy. The removable portion is to be analyzed for radionuclide content as described below.

- The tightly adherent fixed contamination layer should be removed with mixed acid to completely solubilize all radionuclides present. This solubilization is to be conducted using a mixture of nitric acid and hydrochloric acid (i.e., dilute Aqua Regia reagent). Complete radionuclide analyses are to be done on this solution including, as a minimum, ${ }^{137} \mathrm{Cs},{ }^{90} \mathrm{Sr},{ }^{241} \mathrm{Am}$ for beta/gamma spectroscopy analysis, and ${ }^{239} \mathrm{Pu},{ }^{240} \mathrm{Pu}$, ${ }^{238} \mathrm{Pu},{ }^{241} \mathrm{Am},{ }^{243} \mathrm{Cm}$, and ${ }^{244} \mathrm{Cm}$ for alpha spectroscopy (See Sections 3.3 and 3.4 for a complete listing of all analytical work to be done). Also, the best possible estimate of etched surface areas (in $\mathrm{cm}^{2}$ ) are to be determined at this time by photos and dimensional data. If the results can not be reported in units of $\mu \mathrm{Ci} / \mathrm{cm}^{2}$, then the Laboratory will need to provide all the information necessary to develop $\mu \mathrm{Ci} / \mathrm{cm}^{2}$ units on every specimen. The Laboratory must include descriptions of exactly what the reported $\mu \mathrm{Ci} / \mathrm{g}$ metal sample is related to, i.e., is it $\mu \mathrm{Ci} / \mathrm{g}$ of leaching solution having a density of $1 \mathrm{~g} / \mathrm{mL}$, or is in $\mu \mathrm{Ci} / \mathrm{mL}$ (or $\mu \mathrm{Ci} / \mathrm{cc}$ ), or something else. Also, the Laboratory will need to report on the total volume $(\mathrm{mL})$ or total mass $(\mathrm{g})$ depending on what exactly is being reported. This information should be transmitted with every report. The data may also be reported in units of $\mu \mathrm{Ci} / \mathrm{g}$ or $\mathrm{nCi} / \mathrm{g}$.

\subsection{Fixed Contamination Layer Removal Study}

An additional study was added to the characterization of the fixed contamination layer on the metal samples. The additional study (also known as the radioactive film removal study) is to evaluate several reagents and combinations of reagents for removing the fixed contamination layer from B-Cell metal specimens. The purpose of this study is to identify potential decontamination agents that may be used in the final clean-out phase of B-Cell. B-Cell has a stainless steel liner that has been exposed to similar conditions as the stainless steel racks. While not directly related to the data quality process for waste classification of B-Cell dunnage, this study will be accomplished using metal samples collected at the same time as the samples for the characterization study. Thus, the requirements for the fixed contamination layer removal study are included in this SAP. The information gained from the fixed contamination layer removal study will be used to support decision-making related to other studies related to decontamination and closure of B-Cell.

\subsubsection{Sample Preparation for Decontamination Reagent Study}

Requirements set forth for conducting the fixed contamination layer removal study are: 
HNF-2804, Rev. 2

September 1999

- Both the removable and the fixed radionuclide inventory are to be measured.

- The contamination on the edge of the specimens and the removable contamination on the face areas of the specimen will be removed and accounted for prior to the fixed contamination layer removal studies.

- A specially prepared specimen will be used for scanning electron microscope studies of the fixed contamination layer chemistry and structure.

- Obtain and submit a photograph of each specimen, with a millimeter ruler in each frame.

- Obtain and submit data from radiation measurement of the specimen before and after the analytical process.

- Obtain and submit data of measurement of the total surface area of surfaces that underwent the analytical process.

\subsubsection{Specific Actions for Decontamination Reagent Study}

For the fixed contamination layer removal studies, radionuclides in both the removable and the fixed portions will be determined. Removable contamination on the edges is to be removed with a small electropolishing bath, or acceptable alternate, and measured separately. Removable contamination on the sample surface is to be removed in an ultrasonic bath (demineralized water) and measured separately. Following the precleaning actions, the sample dose rate will be measured at contact and at 1 -foot to prepare for the decontamination testing. Different reagents will be tested for decontamination efficiency as given in Table 4. Dose rate data will be taken to follow the dissolution kinetics.

Table 4. Decontamination Reagents to be Tested in Fixed Contamination Layer Removal Study

\begin{tabular}{|c|c|c|c|c|}
\hline 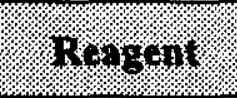 & Wra. & (19.8) & Wort Yine & 2010 \\
\hline $1.6 \mathrm{M}$ Nitric & 1 & $70^{\circ}$ & 4 & N/A \\
\hline $0.25 \mathrm{M}$ Citric & 2 & $70^{\circ}$ & 4 & N/A \\
\hline $2 \mathrm{M} \mathrm{NaOH}$ & 3 & $70^{\circ}$ & 4 & N/A \\
\hline AP* & 4 & $70^{\circ}$ & 2 & Two-stage treatment; water flush between \\
\hline Citrox** & 4 & $70^{\circ}$ & 6 & Second stage of sequence \\
\hline $\mathbf{A P}^{*}$ & 5 & $70^{\circ}$ & 2 & Two-stage treatment; water flush between \\
\hline 1.6M Nitric & 5 & $70^{\circ}$ & 4 & Second stage of sequence \\
\hline $\begin{array}{l}0.1 \mathrm{M} \mathrm{Ce}^{+4} / \\
2 \mathrm{M} \mathrm{Nitric}\end{array}$ & 6 & $70^{\circ}$ & 62 & N/A \\
\hline AP* & 7 & $70^{\circ}$ & 2 & $\begin{array}{l}\text { Two-stage treatment; water flush } \\
\text { between }\end{array}$ \\
\hline $\begin{array}{l}\text { 2M Formic } \\
\text { Acid }\end{array}$ & 7 & $50^{\circ}$ & 4 & Second stage of sequence \\
\hline $\begin{array}{l}\text { 2M Formic } \\
\text { Acid }\end{array}$ & 8 & $70^{\circ}$ & 6 & Single stage of contact \\
\hline
\end{tabular}


HNF-2804, Rev. 2

September 1999

\begin{tabular}{|c|c|c|c|c|}
\hline$x^{2}$ & r. & (1) & Honos. & $401 \%$ \\
\hline $\begin{array}{l}\text { 3M Formic } \\
\text { Acid }\end{array}$ & 9 & $70^{\circ}$ & 6 & Single stage of contact \\
\hline $\begin{array}{l}\text { DuBoise } \\
\text { Alkali Foam }\end{array}$ & 10 & N/A & 1 & $\begin{array}{l}\text { Wash with deionized water and measure } \\
\text { dose; Save wash for analysis }\end{array}$ \\
\hline Repeat foam & 10 & N/A & 1 & N/A \\
\hline Repeat foam & 10 & N/A & 1 & N/A \\
\hline Repeat foam & 10 & N/A & 1 & N/A \\
\hline
\end{tabular}

* $\quad A P=$ Alkaline Permanganate: $2.5 \mathrm{M} \mathrm{NaOH}$ and $0.2 \mathrm{M} \mathrm{KMnO}$

* Citrox $=0.3 \mathrm{M}$ Oxalic and $0.2 \mathrm{M}$ Citric

The final decontamination solution used to remove the fixed contamination layer is to be analyzed to determine removal efficiency.

The residual activity on the specimen is to be measured with a gamma spectroscopy analyzer for maximum sensitivity. If possible, determine if residual activity is on the edges or on the etched surface of the sample. Portable survey instrument data should also be taken. This is necessary because the decontamination factor (DF) is very sensitive to residual quantities. If direct measurement is not possible, remove the residual activity with mixed acids as is done for the waste characterization samples.

To remove any edge contamination, an acidic electropolishing bath may be prepared in a small beaker and the edges subjected to anodic dissolution to remove the rough surface and the trapped nuclides. Sulfuric acid or phosphoric acid are acceptable. Only the edge should be submerged during the cleaning action. This will require four steps to clean the specimen with rinses between to prevent the bath solution from interfering with the fixed contamination layer. Alternately, a moderately concentrated nitric-hydrochloric acid (with a swab) could be used to clean the edges if the effectiveness can be demonstrated.

A specially prepared specimen will be necessary for analysis by scanning electron microscope. Contact with the individuals operating this instrument will be necessary to define the specimen preparation. Any chemistry data that can be provided by microprobe analysis and any physical structure information that can be provided would be very helpful.

\subsubsection{Analytical Procedures For The Fixed Contamination Layer Removal Study}

The following discussion outlines a development program to test various decontamination reagents on metal surface specimens cut from racks in B-Cell 324 Facility. A base case test is outlined below. In addition, it is expected that Scanning Electron Microscope and Electron Dispersion Scanning data will also be gathered from at least one specimen. For all film removal tests, the BWHC cognizant engineer 
will collaborate with the Laboratory personnel performing the work, and will approve any changes to the procedures to be followed. It is probable that additional tests will be performed based on the interim results.

Tests will be conducted in a radiochemistry lab to demonstrate the response of the tightly adherent, fixed contamination layer to various chemical conditions. Analysis will be done on the resultant solutions and specimens to measure the kinetics of dissolution and the completeness of dissolution of the fixed contamination layer. Part or all of a sample may be used for each test. The sample will be cut into various specimens at the Laboratory as directed. Sample identification numbers and cutting diagrams of all samples will be maintained throughout testing so that they are always traceable to the sample identification. The size of each test specimen subjected to a test will be primarily determined by the specimen dose rate and dimensional data.

The active film area of any specimen or portion of specimen should be measured using the best available methods. When specimens are subdivided it is also suggested that other estimates be made of the specimen by weight and by gamma spectroscopy, if possible. This is necessary to define as well as possible, the radioactive film area being subjected to chemistry. Dimensional data and photographs will also be taken. All data are eventually referenced to a unit $\mathrm{cm}^{2}$ area of radioactive film.

Each initial specimen should be given an ID number traceable to a sample identification number, if not already assigned a unique number. Cutting diagrams must be recorded when subdivided. The rack sample locations should be available with the original specimens.

\subsubsection{Specimen Tests}

\subsubsection{Demineralized Water Pretreatment}

Pretreat a specimen by soaking in $50^{\circ} \mathrm{C}$ deionized water for 20 minutes.

\subsubsection{Reagent Testing}

Suspend the specimen in stirred reagent at specified temperature for the specified residence time (see Table 4). Dose rates of the specimen will be collected and recorded every 15 minutes for first hour, every 30 minutes for second hour, and every 60 minutes for the remaining time.

After reagent contact time is done, the specimen will be rinsed and the final dose rate of the specimen taken. Compare the initial dose rate of the specimen to the final dose rate. The DF is calculated using the following formula:

$$
D F=\frac{I}{F}
$$

where: 


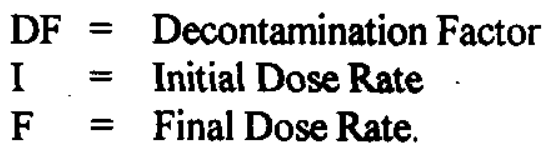

\subsubsection{Residual Contamination Layer Removal}

If the DF is less than or equal to 5, store the specimen. If the DF is greater than 5 , measure the radiation levels of the specimen directly, or remove the residual film left on the specimen with mixed acid (i.e., 3 parts of $3 \mathrm{M}$ hydrochloric acid $[\mathrm{HCl}]$ and 1 part of $3 \mathrm{M}$ nitric acid $\left.\left[\mathrm{HNO}_{3}\right]\right)$, and analyze.

Analyses will need to be performed on the following solutions for each decontamination agent tried:

- Ultrasonic bath solutions

- Reagent solution

- Film strip solution

For each solution, perform radionuclide analyses for ${ }^{137} \mathrm{Cs}$ and ${ }^{241} \mathrm{Am}$ by gamma spectroscopy analysis; ${ }^{90} \mathrm{Sr}$ by chemical separation and beta counting; and ${ }^{239} \mathrm{Pu},{ }^{240} \mathrm{Pu},{ }^{238} \mathrm{Pu},{ }^{241} \mathrm{Am},{ }^{243} \mathrm{Cm}$, and ${ }^{244} \mathrm{Cm}$ by alpha spectroscopy. The initial testing is to be only from beta-gamma counting and total alpha analysis. Subsequent analyses are planned to be done on the final etching solutions that produced the highest decontamination factor. A complete description of the all methods will be documented in a laboratory test procedure.

\subsection{QUALITY ASSURANCE}

\subsection{Sampling Procedures}

All sampling collection, handling and shipping of the rack and vessel metal samples will be accomplished using operating procedures and technical work plans (TWPs) listed in Table 3. The collection of each sample from racks $1 \mathrm{~A}, 2 \mathrm{~A}$, and $2 \mathrm{~B}$ denoted in Figures 4 and 5 is documented on a Sample Log Data Sheet in accordance with the 3I-TWP-98-035 technical work plan.

It should be noted that, due to an administrative error, the TWP for size reducing the 1B Rack did not include collection of samples per this SAP or earlier versions of the SAP. However, seven samples from the connector nozzle array of the 1B rack were collected prior to the waste being removed from B-Cell. Four of the samples collected were shipped to the Laboratory for analysis. 
HNF-2804, Rev. 2

September 1999

\subsection{Sample Custody}

Custody and handling of the samples while within the 324 Facility will be performed in accordance with Section 6.1, Waste Generation Management Plan, in HNF-IP-1264, 324/327 Facilities Stabilization Projects Administrative Manual. Custody and handling of the samples while at the Laboratory will be performed in accordance with the 222-S Laboratory Quality Assurance Plan (Markel 1999), or other comparable Laboratory operation procedures.

\subsection{Analytical Procedures for Waste Characterization Samples}

\subsubsection{General Actions}

Laboratory personnel will analyze either or both the inner and outer surfaces of the specimen. If analyzing only one face at a time such as with the vessel wall specimens, the opposite side will be masked with paraffin, epoxy, or other masking agent, or protected in some manner that ensures that only material of interest is removed. Acid etching of the surface of interest will then be performed using the mixed acid solution on each specimen. Aliquots of the water wash and mixed acid etch solutions will be used to perform the following analyses:

- Gamma Spectroscopy per approved Laboratory protocols for isotopic data

- Alpha Analysis per approved Laboratory protocols for isotopic data (Assume chemical separations necessary to resolve isotopes)

- ${ }^{90} \mathrm{Sr}$ analysis per approved Laboratory protocols.

It is planned that when process vessel surfaces are sampled, the outer surface (that facing the hot cell) will be permanently marked during the cutting process to assist in maintaining the identity of the inner and outer surfaces during analysis. Laboratory difficulties in performing this task may necessitate treating all process vessel sample surfaces at the same time.

The 1B rack specimens will be analyzed for ${ }^{137} \mathrm{Cs}$ and ${ }^{241} \mathrm{Am}$ by gamma spectroscopy analysis; ${ }^{90} \mathrm{Sr}$ by chemical separation and beta counting; and ${ }^{239} \mathrm{Pu}$, ${ }^{240} \mathrm{Pu},{ }^{238} \mathrm{Pu},{ }^{241} \mathrm{Am},{ }^{243} \mathrm{Cm}$, and ${ }^{244} \mathrm{Cm}$ by alpha spectroscopy. Subsequent specimen analyses from other locations will be defined in the SOWs sent to the Laboratory as samples are generated and shipped.

The following tasks are to be performed on each specimen:

- Use an ultrasonic water bath to clean the specimen surfaces of removable contamination. Save the ultrasonic wash solution for analysis.

- Clean the cut edges of the specimen using an electropolish bath. Acceptable substitutes for the electropolishing of the specimen edges are cleaning the cut edges using the same mixed acid solution that will be used to remove the fixed contamination layer from the metal samples, or use of epoxy or other material 
HNF-2804, Rev. 2

September 1999

to mask the cut edges. In all cases, care should be taken to limit disturbing the specimen surfaces that are to be etched.

- Use a 3M nitric acid and $3 M$ hydrochloric acid (dilute Aqua Regia) mixed acid solution to remove fixed contamination layer from the stainless steel samples.

If gross counts of radionuclides indicate that the amounts are trivial and not worth the effort to evaluate isotopic data, then complete the gross analysis to bound the total amount present.

\subsubsection{Specific Actions}

Analytical procedures and test plans to be used by the Laboratory are listed in Table 5.

Table 5. Sample Preparation and Analytical Procedures

\begin{tabular}{|c|c|}
\hline PROCEDURE & TIIII \\
\hline \multicolumn{2}{|c|}{ Sample Preparation by Laboratory } \\
\hline$-\cdots$ & Test Procedure for 324 B-Cell Sample Preparation \\
\hline--- & Test Procedure for 324 B-Cell Film Removal Studies \\
\hline \multicolumn{2}{|c|}{ Laboratory Analytical Procedures } \\
\hline LA-220-101 & High Level Strontium-89, 90 in Aqueous Samples \\
\hline LA-505-161 & $\begin{array}{l}\text { Inductively Coupled Plasma (ICP) Emission Spectrometric } \\
\text { Method for the Thermo Jarrell Ash Type 61E }\end{array}$ \\
\hline LA-505-166 & Treatment Of B-Cell Samples \\
\hline LA-506-101 & $\begin{array}{l}\text { Determination Of Trace Elements And Radionuclides By } \\
\text { ICP/MS Using TJA POEMS }\end{array}$ \\
\hline LA-508-002 & $\begin{array}{l}\text { Detection Limits and Uncertainty Calculations for } \\
\text { Radioisotopic Counting }\end{array}$ \\
\hline LA-508-101 & Alpha And Beta In Liquid Samples \\
\hline LA-519-151 & $\begin{array}{l}\text { Visual Check and Over-The-Top Reading } \\
\text { (to record the sample appearance information) }\end{array}$ \\
\hline LA-548-121 & Preparation of Sample Mounts for GEA \\
\hline LA-953-104 & $\begin{array}{l}\text { Determination Of Plutonium And Americium By Extraction } \\
\text { By TRU-SPEC Resin (also covers Curium) }\end{array}$ \\
\hline LA-925-009 & Determination of Uranium by Kinetic Phosphorescence \\
\hline
\end{tabular}


HNF-2804, Rev. 2

September 1999

\subsection{QA/QC Requirements}

The analytical procedures associated with work on this SAP will adhere to quality assurance and quality standards set forth in the 222-S Laboratory Quality Assurance Plan (Markel 1999) and the Hanford Analytical Services Quality Assurance Requirements Document (HASQARD) (DOE/RL 1998b).

The analytical methods and associated quality control (QC) requirements applicable to each analysis are provided in Table 6 . The listed analytes will be measured for the sample solutions created in this SAP. In addition, any other radionuclides detectable by GEA will be reported. At a minimum, each analytical batch following dissolution will contain a laboratory control sample, a preparation blank, and one duplicate analysis as required by 222-S Laboratory Quality Assurance Plan (Markel 1999). In addition, for gross alpha and metals analyses a post dissolution spike will be included in the analytical batch. Analytical results are to be reported at the $95 \%$ statistical confidence level.

The alpha balance must be closely checked and reported to BWHC. Uranium is not expected to be present through process knowledge. If the sum of the individual alpha emitters is less than the gross alpha minus gross alpha counting error, contact BWHC and conduct analysis for uranium in accordance with the table below. The Laboratory is to take actions as necessary to minimize counting error. If the sum of the individual alpha emitters is still less than gross alpha minus gross alpha counting error, then a meeting will be called between Waste Management Laboratories (WML) and BWHC to initiate a planning session to address the issue.

Table 6. Analytical and Quality Control (QC) Requirements

\begin{tabular}{|c|c|c|c|c|c|}
\hline \multirow[b]{2}{*}{ 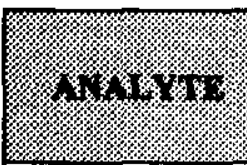 } & \multirow[b]{2}{*}{ 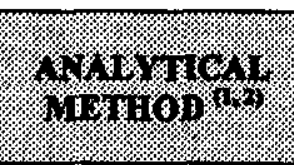 } & \multirow{2}{*}{ 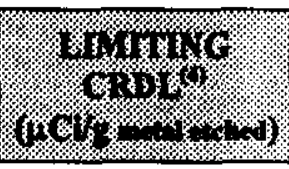 } & \multicolumn{3}{|c|}{ 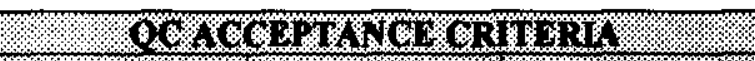 } \\
\hline & & & 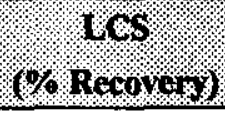 & 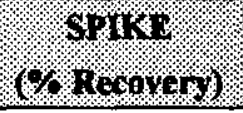 & 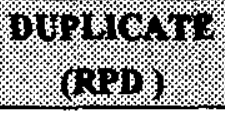 \\
\hline${ }^{137} \mathrm{Cs}$ & GEA & $1 \times 10^{-5}$ & $80-120 \%$ & $\mathrm{~N} / \mathrm{A}$ & $\leq 20 \%$ \\
\hline${ }^{154} \mathrm{Eu}$ & GEA & $1 \times 10^{-5}$ & N/A & N/A & $\leq 20 \%$ \\
\hline${ }^{155} \mathrm{Eu}$ & GEA & $2 \times 10^{-6}$ & N/A & N/A & $\leq 20 \%$ \\
\hline${ }^{60} \mathrm{Co}$ & GEA & $1 \times 10^{-5}$ & $80-120 \%$ & $\mathrm{~N} / \mathrm{A}$ & $\leq 20 \%$ \\
\hline \begin{tabular}{|l}
$\begin{array}{l}\text { All detectable } \\
\text { gamma emitters } \\
\text { not listed above }\end{array}$ \\
\end{tabular} & GEA & $1 \times 10^{-5}$ & N/A & N/A & $\leq 20 \%$ \\
\hline${ }^{90} \mathrm{Sr}$ & $\begin{array}{l}\text { Radiochemical } \\
\text { separation and beta } \\
\text { counting }\end{array}$ & $1 \times 10^{-5}$ & $80-120 \%$ & N/A & $\leq 20 \%$ \\
\hline Gross alpha & $\begin{array}{l}\text { Proportional } \\
\text { Counter }\end{array}$ & $5 \times 10^{-6}$ & $80-120 \%$ & $70-130 \%$ & $\leq 20 \%$ \\
\hline${ }^{238} \mathrm{Pu}$ & $\begin{array}{l}\text { Radiochemical } \\
\text { separation and } \\
\text { AEA }\end{array}$ & $2 \times 10^{-6}$ & N/A & N/A & $\leq 20 \%$ \\
\hline
\end{tabular}




\begin{tabular}{|c|c|c|c|c|c|}
\hline \multirow[b]{2}{*}{ \% } & \multirow[b]{2}{*}{ 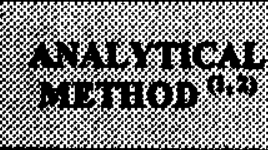 } & \multirow{2}{*}{ (3) } & \multicolumn{3}{|c|}{ 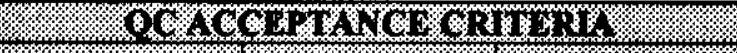 } \\
\hline & & & א. & (6. & 1306 \\
\hline${ }^{239210} \mathrm{Pu}$ & $\begin{array}{l}\text { Radiochemical } \\
\text { separation and } \\
\text { AEA }\end{array}$ & $2 \times 10^{-6}$ & $70-125 \%$ & N/A & $\leq 20 \%$ \\
\hline${ }^{241} \mathrm{Am}$ & $\begin{array}{l}\text { Radiochemical } \\
\text { separation and } \\
\text { AEA }\end{array}$ & $2 \times 10^{-6}$ & $70-125 \%$ & N/A & $\leq 20 \%$ \\
\hline${ }^{243 / 244} \mathrm{Cm}$ & $\begin{array}{l}\text { Radiochemical } \\
\text { separation and } \\
\text { AEA }\end{array}$ & $2 \times 10^{-6}$ & N/A & N/A & $\leq 20 \%$ \\
\hline${ }^{243} \mathrm{Cm}$ & ICP/MS $^{(3)}$ & N/A & N/A & N/A & $\leq 20 \%$ \\
\hline${ }^{244} \mathrm{Cm}$ & $\mathrm{ICP}_{\mathrm{MS}}{ }^{(3)}$ & $\mathbf{N} / \mathbf{A}$ & N/A & N/A & $\leq 20 \%$ \\
\hline $\begin{array}{l}\text { Total Uranium } \\
\text { (supplemental) }\end{array}$ & $\begin{array}{l}\text { Laser kinetic } \\
\text { phosphorescence }\end{array}$ & 1 ppb & $79-125 \%$ & N/A & $\leq 20 \%$ \\
\hline
\end{tabular}

GEA = Gamma Energy Analysis

AEA = Alpha Energy Analysis

ICP/MS = Inductively Coupled Plasma/Mass Spectrometry

N/A = Not applicable for this method

(1) All samples must be in a homogeneous solution prior to analysis.

(2) Sample sizes and counting techniques shall be employed that limit counting error to $<5 \%$. In the event that $<\mathbf{5 \%}$ counting error cannot be attained, the counting error attained shall be reported and the technical basis for the inability to reach the desired maximum counting error shall be included in the report.

(3) This supplemental analysis is to be performed only on one acid etch solution (Sample No. S99BW00063) after the recovery dissolution is completed. This determination is for calculating the ratio of the two isotopes only and CRDLs are not applicable.

(4) Use of detection levels greater than the limiting customer required detection level (CRDL) listed is permissible as long as the analytical result attained by the analysis is at least 10 times the detection level used for that analysis.

Interference from the high ${ }^{137} \mathrm{Cs}$ content in this waste matrix will make reaching the listed limiting CRDL difficult for some gamma emitters (such as ${ }^{154} \mathrm{Eu}^{155} \mathrm{Eu}$ and ${ }^{60} \mathrm{Co}$ ) and gross alpha. Detection levels will be minimized as much as possible in an attempt to reach the limiting CRDL specified.

If ${ }^{154} \mathrm{Eu},{ }^{155} \mathrm{Eu},{ }^{60} \mathrm{Co}$ or gross alpha are detected and the analytical result is less than 10 times the detection level used for the analysis, then the technical basis for the inability to reach the required detection level will be reported in the letter report.

If ${ }^{154} \mathrm{Eu},{ }^{155} \mathrm{Eu}$ and ${ }^{60} \mathrm{Co}$ are not detected; the detection limit must be less than $1 \%$ of the Cs result and less than $1 \%$ of the respective Category 1 limit. If either of these criteria $(<1 \%$ of the Cs result or

$<1 \%$ of the respective category $1 \mathrm{limit}$ ) are not met, the isotope must be reported as $<$ the detection limit used and the technical basis for the lack of ability to reach a lower detection limit must be included in the report of results.

Water wash sample Limiting CRDLs can be a factor of 10 higher than those listed, when restricted by sample volume.

ICP/MS analysis for atomic masses 243 and 244 on the acid etch solution of sample S99BW00063 will be performed in an attempt to establish the relative abundances of ${ }^{243} \mathrm{Cm}$ and ${ }^{244} \mathrm{Cm}$. Currently, only estimates of the relative abundances of these two isotopes are available from ORIGEN data assuming reactor fuel having 20,000 
megawatt-days per ton (MWD/T) exposure and 10 years of cooling. An aliquot that has been taken through the $\mathrm{Pu} / \mathrm{Am}$ separation without the addition of the ${ }^{243} \mathrm{Am}$ tracer will be used for this analysis. These results will be used to obtain a ratio of the two-curium isotopes. The Laboratory will provide in the written report the technical basis of the ratio.

\subsubsection{Quality Control Analyses}

Laboratory Control Sample (LCS) - A known amount of analyte in a known matrix that is carried through the analytical method. This sample provides an indication of analytical method and instrument performance. Control limits for LCS recoveries are governed by historical method performance at a $95 \%$ confidence level.

Preparation Blank - A blank that has been carried through the entire dissolution and analytical process. The blank will consist of all reagents used during the dissolution of the samples. Blank values should be less than the minimum detectable activity or less than $5 \%$ of the sample result.

Duplicate - A second aliquot of a sample that is carried through the analytical process. A relative percent difference (RPD) between the sample and duplicate results will be determined. Acceptable sample precision is usually $\leq 20 \%$ RPD. RPD is dependent upon counting error.

Spike - A known amount of the isotope of interest that is added to a second aliquot of sample. Spike recoveries give an indication of matrix interference (used in gross alpha analysis).

Carrier - A known amount of the naturally occurring element of interest added to the sample. The carrier demonstrates the same chemical behavior as the isotope of interest. The recovery is not reported, but is used to correct results for losses incurred during separation (used in ${ }^{90} \mathrm{~S} r$ analysis).

Tracer - A known amount of a different radionuclide than the isotope of interest added to the sample. The tracer demonstrates the same chemical behavior as the isotope of interest. The recovery is not reported, but is used to correct results for losses incurred during separation (used in ${ }^{238} \mathrm{Pu},{ }^{239 / 240} \mathrm{Pu},{ }^{241} \mathrm{Am},{ }^{243 / 244} \mathrm{Cm}$ ).

\subsection{Data Reporting and Management}

\subsubsection{Reporting of Analytical Data}

Validated laboratory results will be provided as required based on daily communication of project status. A final letter report from the Laboratory consisting of a case narrative, sample breakdown diagrams and the data summary tables will be provided at the completion of each batch of analyses. The narrative will include discussion of the methodology that was used to obtain homogeneous 
solutions and all documented sample weights and volumes during the analytical process (i.e., tracking of all aliquots removed for the various analyses). Any supplemental analysis results will be provided in a separate report, if required.

Color photographs will be provided on a compact disk that will be attached to the letter report. At the completion of all analytical work, final weights and volumes of all solutions will be recorded and the sample bottles will be sealed prior to storage.

The weight of the metal sample originally etched is critical to the results of these analyses. The Laboratory will determine the effective weight of the etched samples by determining the radioactive film surface area etched and the total metal sample surface area using photographs of the epoxy-masked or electropolished metal samples and applying this ratio to the total weight of the sample determined prior to etching.

The Laboratory will report final radionuclide analytical results in terms of $\mathrm{nCi} / \mathrm{cm}^{2}, \mathrm{nCi} / \mathrm{g}$ or $\mu \mathrm{Ci} / \mathrm{g}$. In addition, the Laboratory will provide a summary of the data used in making these calculations of analytical results, including total activity for the sample, radioactive film area etched from the sample, total surface area of the sample, total weight of the sample, and the effective weight of the etched sample in the written report of the analytical results.

\subsubsection{Communications}

Open and frequent communications between the Laboratory and BWHC will be provided. Mr. Karl N. Pool (372-2557 or 539-4283) will act as the WML point of contact for this path forward. Mr. Rich Hobart (373-2316 or 542-2720) or Dr. Robin Hill (376-4808) will act as BWHC points of contact for this work, unless otherwise specified in a SOW. Any unusual results will be discussed with the BWHC points of contact as soon as possible. A memo to file documenting conversations and decision making will be prepared and concurred with by both parties and appended to this plan.

\subsubsection{Data Verification and Validation}

All analytical data will be verified and validated in accordance with the $222-\mathrm{S}$ Laboratory Quality Assurance Plan (Markel 1999) and/or the Hanford Analytical Services Quality Assurance Requirements Document (HASQARD) (DOE/RL $1998 \mathrm{~b})$ prior to reporting to BWHC.

\subsection{SCHEDULE}

Shipments of samples to the Laboratory after the 1B rack samples and the first shipment of 1A rack samples were accompanied by a detailed SOW that clearly states any deviations from or 
HNF-2804, Rev. 2

September 1999

additions to this SAP. Field activities were scheduled to begin in November 1998 and be completed by September 1999. The results of the analysis of the samples will be reported in a data analysis document to be issued by September 30, 1999.

\section{S.0 REFERENCES}

Barnett, J. M. 1998. Data Quality Objectives for the B-Cell Waste Stream Classification Sampling, HNF-2596, Rev. 1.

Bilson, H.E. 1999. Contract NO. DE-AC-06-96RL13200-Disposal of Greater Than Class C Waste (GTCC) as Defined by the U.S. Nuclear Regulatory Commission (NRC). Correspondence No. 9955456 from H.E. Bilson (DOE/RL) to R.D. Hanson (FDH), dated August 5, 1999.

DOE Order 5820.2A. Radioactive Waste Management. U.S. Department of Energy, Washington, D.C.

DOE/RL. 1998a. 324 Building Radiochemical Engineering Cells, High-Level Vault, LowLevel Vault, and Associated Areas Closure Plan. DOE/RL-96-73, Revision 1. U.S. Department of Energy, Richland, Washington.

DOE/RL. 1998b. Hanford Analytical Services Quality Assurance Requirements Document.

DOE/RL-96-68, Revision 2, September 30, 1998. Department of Energy, Richland, Washington.

DOT. 1998. Regulations Related to Transportation. Research and Special Programs

Administration. 49 CFR Parts 100 to 185. U.S. Department of Transportation, Washington, D.C.

Durham, J. S. 1998. Technical Basis for Characterization of B-Cell Waste for Shipment in the 3-82B Shipping Cask. HNF-3636, Revision 1.

Hobart, R. L., R. M. Millikin. 1997. 324/327 Facilities Special-Case Waste Assessment and Disposition Alternatives Analysis. HNF-1730, Revision 0. B\&W Hanford Company, Richland, Washington.

Hobart, R. L. 1998. 324 Facility Special-Case Waste Assessment in Support of 324 Closure (TPA Milestone M-89-05). HNF-2570, Revision 1. B\&W Hanford Company Richland, Washington.

Jensen, L., S. R. Wilmarth. 1998. Statistically Based Sampling of Pipes, Tanks, and Racks in BCell. Letter Report \# 7A120-98-926, dated June 1, 1998. Prepared by Lockheed Martin Hanford Corporation for B\&W Hanford Company, Richland, Washington.

Markel, L.P. 1999. 222-S Laboratory Quality Assurance Plan. HNF-SC-CP-QAPP-016, Revision 3C. Prepared by Waste Management Federal Services of Hanford, Inc., Richland, Washington. 
Meeks, A. M., J.A. Chapman. 1997. Development of the Remote-Handled Transuranic Waste Radioassay Data Quality Objectives. Prepared by Oak Ridge National Laboratory, Oak Ridge, Tennessee.

MMT of Tennessee, Inc. 1998. Rad Services Manual for 3-82B Shielded Transportation Cask RSM-006, Revision 28. MMT of Tennessee, Inc., 1000 Clearview Court, Oak Ridge, TN.

NRC. 1997. Certificate of Compliance for Radioactive Materials Package - Model 3-82B. Certificate Number 6574, Package Number USA/6574/B(.). U.S. Nuclear Regulatory Commission, Washington, D.C.

Rasmussen, D. E. 1999a. Waste Designation Basis for B-Cell Grout Container GC-127. Memorandum BWHC 19500-DER-1999-005, dated June 17, 1999.

Rasmussen, D. E. 1999b. Waste Designation Basis for B-Cell Grout Container GC-128. Memorandum BWHC 19500-DER-1999-006, dated June 17, 1999.

Rasmussen, D. E. 1999c. Waste Designation Basis for B-Cell Grout Container GC-129. Memorandum BWHC 19500-DER-1999-007, dated June 24, 1999.

Rasmussen, D. E. 1999d. Waste Designation Basis for B-Cell Grout Container GC-133. Memorandum BWHC 19500-DER-1999-008, dated June 17, 1999.

Rasmussen, D. E. 1999e. Waste Designation Basis for B-Cell Grout Container GC-135. Memorandum BWHC 19500-DER-1999-010, dated June 24, 1999.

Rasmussen, D. E. 1999f. Waste Designation Basis for B-Cell Grout Container GC-136. Memorandum BWHC 19500-DER-1999-011, dated July 1, 1999.

Rasmussen, D. E. 1999g. Waste Designation Basis for B-Cell Grout Container GC-137. Memorandum BWHC 19500-DER-1999-012, dated July 2, 1999.

Rasmussen, D. E. 1999h. Waste Designation Basis for B-Cell Grout Container GC-139. Memorandum BWHC 19500-DER-1999-013, dated July 6, 1999.

SEG. 1991. Safety Analysis Report for the 3-82B Radwaste Shipping Cask. STD-R-02-014, Rev. 8. Scientific Ecology Group (SEG), Inc., P.O. Box 2530, 1560 Bear Creek Road, Oak Ridge, TN.

Shelor. 1999. Basis for Storing Grout Containers in 324 Building C-Cell. HNF-4677, Revision 0 . B\&W Hanford Company, Richland, Washington.

Webb, R. H. 1997. 324 Building Safety Analysis Report. HNF-SD-SPJ-SAR-001, Rev 0. Prepared by Parsons Infrastructure and Technology Group, Inc. for B\&W Hanford Company, Richland, Washington. 
HNF-2804, Rev. 2

September 1999

WMH. 1998. Hanford Site Solid Waste Acceptance Criteria. WHC-EP-0063-4, Page Change \#5), Published May 1996. Prepared by Waste Management Federal Services of Hanford, Inc. (WMH), Richland, Washington.

WMNW. 1998. 3-82B Shipping Cask Shielding Analysis. EBU-RCAL-002. Prepared by Waste Management Northwest (WMNW), Richland, Washington. 
HNF-2804, Rev. 2

September 1999

APPENDIX A

\section{Data Quality Process Summary}


HNF-2804, Rev. 2

September 1999

\section{APPENDIX A - DATA OUALITY PROCESS SUMMARY}

\subsection{DATA QUALITY PROCESS}

The quality objectives and goals for this study were originally defined in HNF-2596, Data Quality Objectives for the B-Cell Waste Stream Classification Sampling (Barnett 1998). Since publication of the Data Quality Objective (DQO) document, further iterations of the data quality process have resulted in updates of the objectives and further definitions of the objectives of this study. A formal Data Quality Objective (DQO) process was not performed or required, but elements of the DQO process, such as data quality analysis, are incorporated as appropriate. The revised data quality process for the fixed contamination layer characterization study after the initial analyses on the 1B rack samples and the first batch of $1 \mathrm{~A} / 2 \mathrm{~B}$ samples is summarized here.

The objectives of the revised data quality process summarized here are formulated with one endpoint in mind - the use of radioassay needs to be performed at a quality level that assures compliance with transportation and waste acceptance criteria. A graded approach is used where the closer a waste shipment is to the limit, the better the measurement accuracy should be. It does not necessarily mean that a radioassay measurement must be made within a few percent, but rather, that when the uncertainty of the radioassay is added to the mean, the resulting value does not exceed an acceptable limit (Meeks and Chapman 1997).

\subsection{Problem Statement}

\subsubsection{Historical Background}

The Hanford Site, located adjacent to and north of Richland, Washington, is operated by DOE/RL. The 324 Building is located in the 300 Area of the Hanford Site. The 324 Building was constructed in the 1960s to support materials and chemical process research and development activities ranging from laboratory/bench-scale studies to full engineering-scale pilot plant demonstrations. In the mid-1990s, it was determined that dangerous waste and waste residues were being stored for greater than 90 days in the 324 Building Radiochemical Engineering Cells (REC) and the High-Level Vault/Low-Level Vault tanks [these areas are not Resource Conservation and Recovery Act of 1976 (RCRA) permitted portions of the 324 Building]. The dispersible contamination found on the floor of B-Cell is designated dangerous waste.

Through the Hanford Federal Facility Agreement and Consent Order (Tri-Party Agreement) Milestone M-89, agreement was reached to close the nonpermitted RCRA unit in the 324 Building. This closure plan, managed under TPA Milestone M-20-55, addresses the identified building areas targeted by the TriParty Agreement and provides commitments to achieve the highest degree of compliance practicable, given the special technical difficulties of managing mixed waste that contains high-activity radioactive materials and the physical limitations of working remotely in the areas within the subject closure unit. 
The latest revision to the 324 Building Radiochemical Engineering Cells, HighLevel Vault, Low-Level Vault, and Associated Areas Closure Plan (DOE/RL, 1998a) was submitted to the Washington State Department of Ecology (Ecology) on March 31, 1998. The closure plan incorporated decisions and agreements made during negotiations and workshops held between Ecology, DOE/RL, and contractors. The workshops and meetings were developed as a unique approach to foster teamwork and to develop consensus in the closure plan revisions.

B-Cell was used to demonstrate chemical engineering pilot-scale processes for radioactive waste management programs. These programs left B-Cell filled with equipment that is highly contaminated with radioactive waste, radioactive materials, and materials that have been designated as mixed waste (DOE/RL 1998a). Additionally, B-Cell contains dispersible (i.e., easily spreadable or removable) material containing mixed-waste contaminants (heavy metals).

Three equipment racks (1 A, 1B, and 2A) are located along the B-Cell east wall. Each rack has 2 tanks that were used for different purposes. The current disposal plan for the racks, structural components, and tanks is to cut them into manageable-size pieces for shipment as LLW to the Hanford Site burial grounds. The process tanks with heel residues will be packaged for disposition as mixed TRU waste as the tanks are sectioned. The vessels and tanks on the racks are as follows (Hobart 1998):

- Rack 1A houses Tank 113 and Tank 115. Tank 113 was used as an evaporator vessel. Tank 115 was used as an acid fractionator reboiler.

- Rack 1B houses Tank 112 and Tank 114. Tank 112 was used for HLV liquid processing. Tank 114 was used as a melter feed tank supporting the waste vitrification process.

- Rack 2A houses Tank 116 and Tank 118 that were used to support the off-gas system and condenser system.

The B-Cell activities are summarized in Table A-1. Periods listed as 'no activity' indicate that no project or R\&D activities were occurring in the cell during that time.

Table A-1. Chronology of B-Cell Activities

\begin{tabular}{|l|c|}
\hline $\begin{array}{l}\text { Waste Solidification Engineering Prototype Program } \\
\text { (WSEP) }\end{array}$ & $1966-1972$ \\
\hline No Activity * & $1972-1976$ \\
\hline Nuclear Waste Vitrification Project (NWVP) & $1976-1979$ \\
\hline No Activity* & $1979-1981$ \\
\hline Zeolite Vitrification Demonstration Project (ZVP) & 1981 \\
\hline $\begin{array}{l}\text { Pilot-scale Radioactive Liquid-Fed Ceramic Melter } \\
\text { (RLFCM) testing task (includes cell prep and installation }\end{array}$ & $1982-1986$ \\
\hline
\end{tabular}


HNF-2804, Rev. 2

September 1999

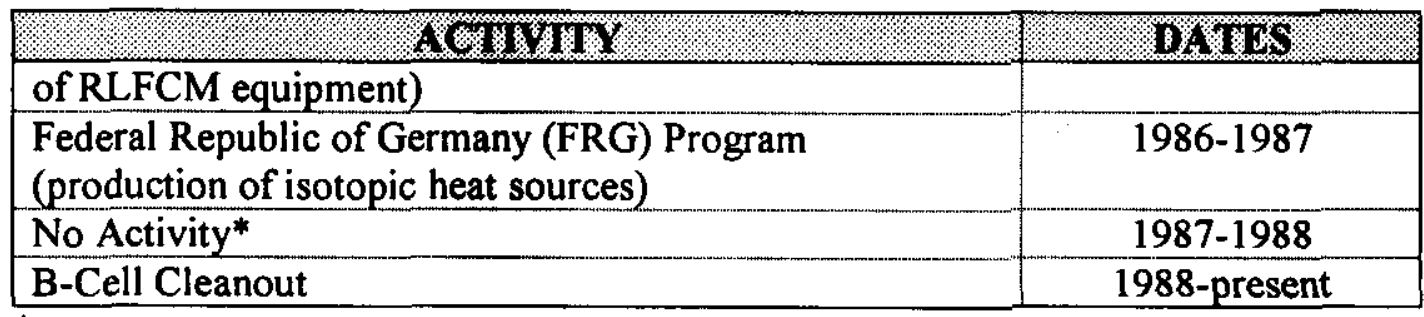

Periods listed as 'no activity' indicate that no project or R\&D activities were occurring in the cell during that time.

\subsubsection{Problem Statement}

The B-Cell in 324 Facility is scheduled for closure. The rack, tank, and vessel dunnage that is not designated as special-case waste (Hobart and Millikin 1997, and Hobart 1998) must be characterized to determine whether this waste will be classified as low-level waste or as TRU waste.

\subsubsection{Problem Statement}

Problem : Currently available information is not sufficient to determine the waste classification of the B-Cell dunnage.

Designation of B-Cell waste to date has previously relied on process knowledge and limited data on the removable contamination on the structural metal material. Prior to 1997, the basis for shipping B-Cell waste to the Hanford burial grounds was based on three smear samples obtained from rinsed surfaces of B-Cell waste in 1993. These samples, representing the removable contamination present, were used to establish the ratio of ${ }^{90} \mathrm{Sr}$ to ${ }^{137} \mathrm{Cs}$. The alpha content was not explicitly determined. Three additional smears were obtained for rinsed surfaces of non-waste material in B-Cell in 1998. The data from these six smears were used to develop a technical basis for shipping B-Cell waste to the burial grounds as LLW (Durham 1998).

Upon review of the Durham document, it was felt that the waste characterization needed a more in-depth study. Process knowledge indicates that most of the nondispersible B-Cell contamination is fixed and the isotopic distribution of radionuclides in the fixed contamination layer may be significantly different than that of the residual removable contamination.

To minimize programmatic risks of improperly classifying radioactive waste, additional data are needed to supplement existing knowledge regarding waste characteristics. The characterization information developed as part of this data quality process will provide data to fully classify the B-Cell dunnage wastes. 
HNF-2804, Rev. 2

September 1999

\subsection{Decision Statements}

To avoid misclassification of B-Cell dunnage wastes, the following principal question must be answered:

Do the radionuclide characteristics of the dunnage wastes from $B$-Cell exceed the LLW waste acceptance criteria?

If the metal wastes are designated as TRU, then the waste must not be grouted before shipping to the Hanford waste contractor for disposition. Any waste designated as TRU will eventually need to be prepared and packaged by the waste contractor in such a way as to meet any requirements established by the Waste Isolation Pilot Plant (WIPP), which is an underground repository used to permanently dispose of defense-generated transuranic waste.

\section{Inputs}

\subsubsection{Key Decision Inputs}

The following inputs are required to support the decision statement made in Appendix A, Section 1.2:

\section{DECISION}

Do the radionuclide characteristics of the dunnage wastes from $B$-Cell exceed the $L L W$ waste acceptance criteria?

\section{INPUT}

- Sampling of the rack, tank, and vessel metal structures in B-Cell

- Laboratory analysis of the fixed radioactive contamination layer on the metal samples $\Rightarrow$ TRU content (plutonium, americium,

$$
\begin{aligned}
& \Rightarrow{ }^{137} \mathrm{Cs} \\
& \Rightarrow{ }^{90} \mathrm{Sr} \\
& \Rightarrow \text { Other gamma emitters }
\end{aligned}
$$

Analytical determinations are critical for those key radionuclides that will be used in development of the scaling factors, namely ${ }^{137} \mathrm{Cs}$ and the TRU radionuclides.

\subsubsection{Regulatory Inputs}

The waste contractor at the Hanford site has prepared a solid waste acceptance program to ensure that waste sent to them for disposition complies with all environmental, safety, and operational requirements. The Hanford Solid Waste Acceptance Criteria document, HNF-EP-0063, Revision 5 (WMH 1998), sets forth the criteria for acceptance of radioactive waste as mandated by DOE Order 5820.2A. 
HNF-2804, Rev. 2

September 1999

\subsubsection{General Waste Acceptance Criteria}

The following criteria apply to the acceptance of all waste by the Hanford waste contractor (WMH 1998):

The major radionuclides in the waste and the concentration of each major radionuclide must be established with sufficient sensitivity and accuracy to properly classify and manage the waste in accordance with the treatment, storage, and/or disposal (TSD) unit-specific radiological limits (DOE Order 5820.2A).

For the purposes of the radiological criteria in HNF-EP-0063, major radionuclides are defined as those radionuclides that meet any of the following conditions.

- Any TRU radionuclide present in the waste in concentration exceeding $1 \mathrm{nCi} / \mathrm{g}$. NOTE: transuranic (TRU) waste is defined as waste containing more than $100 \mathrm{nCi}$ of alpha-emitting transuranic isotopes per gram of waste, with half-lives greater than 20 years, except for: (1) high-level waste; (2) waste that the Secretary (of Energy) has determined, with the concurrence of the EPA Administrator, does not need the degree of isolation required by the disposal regulations; or (3) waste that the Nuclear Regulatory Commission has approved for disposal on a case-by-case basis in accordance with 10 CFR 61 (Public Law 102-579: Waste Isolation Pilot Plant Land Withdrawal Act). (WMH 1998)

- Any fissionable radionuclide present in the waste in a quantity exceeding 0.1 fissile gram equivalents (FGE) per container.

- Any radionuclide that accounts for more than $1 \%$ of the total radiological activity of the waste.

- Any radionuclide present in concentration exceeding $1 \%$ of its respective Category 1 limit (See HNF-EP-0063, Appendix A, Table A2. NOTE: this reporting limit does not apply to TRU waste).

- Any mobile radionuclide present in concentration that exceeds its reporting limit (See HNF-EP-0063, Appendix A, Table A-2. NOTE: this reporting limit does not apply to TRU waste).

\subsubsection{Low-Level Waste Criteria}

The low-level burial grounds (LLBG) are a land disposal unit for controlled burial of low-level radioactive waste. A waste must meet all of the following conditions to be disposed in the LLBG:

- TRU content limit - TRU content (as calculated by method A. 1 of Appendix A) shall not exceed $100 \mathrm{nCi}$ per gram of waste (DOE Order 5820.2A)

- Waste category (as calculated by methods A.4 and A.5 of Appendix A, HNF-EP-0063) shall not exceed Category 3, except with an analysis 
coordinated by the WMH acceptance organization demonstrating that the LLBG Performance Assessment conditions are met.

- Category 3 waste (as calculated by methods A.4 and A.5 of Appendix A, HNF-EP-0063) can be disposed of only if the waste meets one of the following waste form stability criteria:

- Packaging in a High Integrity Container (HIC) that meets the testing requirements of the Hanford High Integrity Container, 300Year specification

- Packaging in a HIC approved by the WMH acceptance organization.

- Stabilization in concrete or other stabilization agents. The stabilized waste must meet the leach index and compression strength criteria of the NRC Technical Position Paper on Waste Form, Section C.2 and Appendix A of HNF-EP-0063.

- Inherently stable waste that meets the stability requirements of 10 CFR 61.56 and the NRC Technical Position Paper on Waste Form.

- Mobile radionuclides - If the concentration of any mobile radionuclide exceeds the Mobile Radionuclide Reporting Limit of Appendix A, Table A-2, stabilization could be required. WMH will perform a caseby-case evaluation against the LLBG performance assessment to determine whether the waste requires stabilization to meet the groundwater pathway dose criteria. Stabilization normally would consist of placement of the waste container in a HIC, but additional stabilization might be required based on a number of factors such as waste form and radionuclide content. The WMH acceptance organization will coordinate this evaluation.

- NRC Class C limit - Waste shall not exceed the NRC Class C limits (as calculated by method A.6 of Appendix A of HNF-EP-0063) (DOE Order 5820.2A).

- ISB limits - Waste must meet the applicable Interim Safety Basis (ISB) limits for the LLBG (as calculated by method A. 7 of Appendix A of HNF-EP-0063), with the following exception: if a combustible waste exceeds the combustible waste limit, but does not exceed the noncombustible waste limit, the WMH acceptance organization can coordinate an evaluation to determine whether segregation or stabilization can be used to mitigate the combustibility hazard .

Contact-handled waste shall not exceed 1 milliSievert per hour (100 millirem per hour) at 30 centimeters ( 1 foot) from the waste package and 2 milliSieverts per hour (200 millirem per hour) on the surface of the package, except that a package larger than 208 liters may have a marked point on the bottom or side with a surface dose rate of up to 10 milliSieverts per hour (1,000 millirem per hour) as long as the 30 centimeter dose rate limit is not exceeded (DOE Order 5820.2A, HSCRM$1)$. 
Remote-handled waste shall meet the applicable dose rate restrictions of DOT or an approved packaging safety analysis. Remote-handled waste shall be configured for unloading such that personnel exposures are maintained as low as reasonably achievable (ALARA), and in no case shall exceed 100 millirem per hour exposure rate.

\subsubsection{TRU Waste Criteria}

To determine whether a waste is TRU, compute the sum of the specific activity of the alpha-emitting radionuclides having half-lives greater than 20 years. These radionuclides are identified by footnote (d) in Table A-2 of $\mathrm{HNF}$-EP-0063. If the total alpha specific activity exceeds $100 \mathrm{nCi}$ per gram, the waste is TRU.

The following are conventions regarding concentration averaging that shall apply to the TRU determination (WMH 1998):

- The concentration applies to the contents of a single waste package at the time of assay (DOE Order 5820.2A).

- The mass of the waste container and any shielding shall not be used in calculating the TRU concentration of the waste (DOE Order 5820.2A).

- The mass of liners, void fillers, sorbents or stabilizing agents added subsequent to generation of the waste generally should not be used in calculating the TRU concentration of the waste. There are, however, certain cases in which these materials are implicitly part of the waste generating process (e.g., liners used in hot cells for packaging before load-out, grouting of waste for reduction of dispersible contamination, sorbents added to aid in removal of sludges from pits or sumps).

\subsubsection{Thermal Power Criteria for Waste}

The thermal power of the waste in a container is calculated from the concentration of radionuclides in the waste and the heat of decay from Table A-1 (WMH 1998). The thermal power calculation is performed in the following steps:

1. The concentration of each radionuclide (expressed in curies per cubic meter) is multiplied by the heat of decay for that nuclide from Table A-1 (WMH 1998), yielding the heat of decay for each in units of watts per cubic meter

2. Thermal power is the sum of the heat of decay of all radionuclides in the waste. The heat generation from radioactive decay in the waste package must not exceed 3.5 watts per $\mathrm{m}^{3}$, otherwise an evaluation of the waste package is necessary to ensure the heat does not affect the integrity of the container or surrounding containers in the LLBG. The 3-82B shipping cask is limited to $205 \mathrm{BTU} / \mathrm{hr}$ or 60 watts (SEG, 1991). 
HNF-2804, Rev. 2

September 1999

\subsubsection{Category 1 Determination}

Classification of waste as Category 1 or greater than Category 1 is a sum of fractions calculation, performed in the following steps (WMH 1998):

1. The concentration of each nuclide (expressed in curies per cubic meter) is divided by its respective Category 1 limit (Table A-2 of HNF-EP-0063).

2. The resulting values are added to form the sum of fractions.

3. If the sum of fractions is less than or equal to 1, the waste is Category 1. If the sum of fractions exceeds 1 , the waste is greater than Category 1 , and the Category 3 determination must be performed to classify the waste.

\subsubsection{Category 3 Determination}

Category 3 determination is performed in the same way as the Category 1 calculation, only using the Category 3 limits from Table A-2 as follows (HNF-EP-0063):

1. The concentration of each nuclide (expressed in curies per cubic meter, $\mathrm{Ci} / \mathrm{m}^{3}$ ) is divided by its respective Category 3 limit from Table A-2 in HNF-EP-0063).

2. The resulting values are added to form a sum of fractions.

3. If the sum of fractions is less than or equal to 1 , the waste is Category 3 . If the sum of fractions exceeds 1 , the waste is greater than Category 3 , and is prohibited from disposal unless additional evaluation is performed.

\subsubsection{NRC Class C Determination}

The prohibition on disposal of NRC Greater Than Class $C$ waste has been waived (Bilson 1999) based on implementation of the new DOE waste management Order, 435.1, and is not longer a waste acceptance criteria for LLW disposal.

\subsubsection{Mobile Radionuclide Determination}

This is a simple comparison of the concentration of each mobile radionuclide $\left({ }^{3} \mathrm{H},{ }^{14} \mathrm{C},{ }^{36} \mathrm{Cl},{ }^{79} \mathrm{Se},{ }^{93} \mathrm{Mo},{ }^{99} \mathrm{Tc},{ }^{129} \mathrm{I},{ }^{187} \mathrm{Re}\right.$, Total $\mathrm{U}$, and ${ }^{237} \mathrm{~Np}$ ) against its respective reporting value from Table A-2 of HNF-EP0063 . If a reporting limit is exceeded, then an evaluation of the disposal conditions applicable to the waste is required before disposal of the waste can occur. 
HNF-2804, Rev. 2

September 1999

\subsubsection{Summary of HNF-EP-0063 Appendix A Tables}

Data from HNF-EP-0063 Appendix tables A-1 and A-2 are summarized in Tables A-2 and A-3 for radionuclides applicable to B-Cell waste characterization.

Table A-2. Applicable Conversion Factors For General Radiological Calculations (a)

\begin{tabular}{|c|c|c|c|c|}
\hline 609013 & 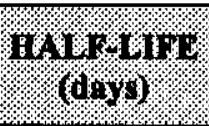 & 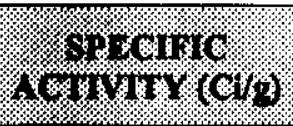 & 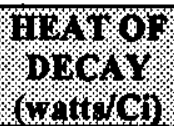 & GMar \\
\hline${ }^{90} \mathrm{Sr}-{ }^{90} \mathrm{Y}^{(\mathrm{b})}$ & $1.0512 \mathrm{E} 04$ & $2.76 \mathrm{E} 02$ & $5.54 \mathrm{E}-03$ & $3.04 \mathrm{E}-03$ \\
\hline${ }^{137} \mathrm{Cs}-{ }^{137 \mathrm{~m}} \mathrm{Ba}{ }^{(6)}$ & $1.0983 \mathrm{E} 04$ & $1.69 \mathrm{E} 02$ & $3.36 \mathrm{E}-03$ & $7.44 \mathrm{E}-05$ \\
\hline${ }^{154} \mathrm{Eu}$ & $3.1385 \mathrm{E} 03$ & $2.70 \mathrm{E} 02$ & $8.77 \mathrm{E}-03$ & $6.66 \mathrm{E}-04$ \\
\hline${ }^{155} \mathrm{Eu}$ & $1.7390 \mathrm{E} 03$ & $4.84 \mathrm{E} 02$ & $6.53 \mathrm{E}-04$ & $9.65 \mathrm{E}-05$ \\
\hline${ }^{238} \mathrm{Pu}$ & $3.2032 \mathrm{E} 04$ & $1.71 \mathrm{E} 01$ & $3.31 \mathrm{E}-02$ & $9.13 \mathrm{E}-01$ \\
\hline${ }^{239} \mathrm{Pu}$ & $8.8060 \mathrm{E} 06$ & $6.21 \mathrm{E}-02$ & $3.11 \mathrm{E}-02$ & $1.00 \mathrm{E} 00$ \\
\hline${ }^{240} \mathrm{Pu}$ & $2.3971 \mathrm{E} 06$ & $2.28 \mathrm{E}-01$ & $3.10 \mathrm{E}-02$ & $1.00 \mathrm{E} 00$ \\
\hline${ }^{241} \mathrm{Am}$ & $1.5786 \mathrm{E} 05$ & $3.44 \mathrm{E} 00$ & $3.33 \mathrm{E}-02$ & $1.03 \mathrm{E} 00$ \\
\hline${ }^{243} \mathrm{Cm}$ & $1.0629 \mathrm{E} 04$ & $5.16 \mathrm{E} 01$ & $3.73 \mathrm{E}-02$ & $7.15 \mathrm{E}-01$ \\
\hline${ }^{244} \mathrm{Cm}$ & $6.6109 \mathrm{E} 03$ & $8.09 \mathrm{E} 01$ & $3.50 \mathrm{E}-02$ & $5.77 \mathrm{E}-01$ \\
\hline
\end{tabular}

(a) Radionuclides applicable to B-Cell waste characterization are from (HNF-EP-0063, Table A-1).

(b) When these parent-daughter pairs are in secular equilibrium, only the activity of the parent nuclide should be considered in performing the calculations, e.g., if ${ }^{90} \mathrm{Sr}-{ }^{90} \mathrm{Y}$ are in secular equilibrium in the waste, the thermal power for both nuclides would be determined by multiplying the ${ }^{90} \mathrm{Sr}$ activity by the heat of decay for the ${ }^{90} \mathrm{Sr}-{ }^{90} \mathrm{Y}$ pair.

Table A-3. Applicable Low-Level Burial Grounds Radiological Content Limits (a)

\begin{tabular}{|c|c|c|c|c|c|}
\hline SOPOPF: & 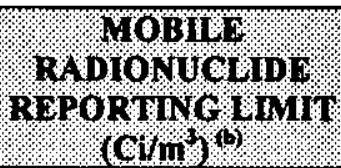 & 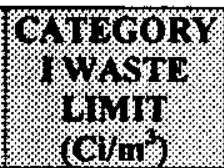 & 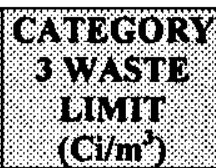 & 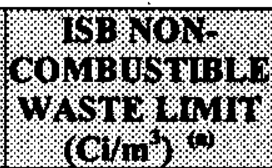 & 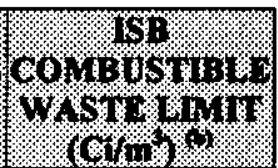 \\
\hline \multicolumn{6}{|c|}{ Applicable Radionuclides } \\
\hline${ }^{90} \mathrm{Sr}-{ }^{90} \mathrm{Y}$ & $\mathrm{NL}^{(\mathrm{c})}$ & $1.6 \mathrm{E}-2$ & $5.4 \mathrm{E} 4$ & $1.50 \mathrm{E} 4$ & 3.75E2 \\
\hline${ }^{137} \mathrm{Cs}-{ }^{137 \mathrm{~m}} \mathrm{Ba}$ & NL & $5.5 \mathrm{E}-3$ & $1.2 \mathrm{E} 4$ & $1.20 \mathrm{E} 5$ & $3.00 \mathrm{E} 3$ \\
\hline${ }^{154} \mathrm{Eu}$ & NL & $7.5 \mathrm{E}-1$ & NL & $1.32 \mathrm{E} 4$ & $3.30 \mathrm{E} 2$ \\
\hline${ }^{155} \mathrm{Eu}$ & NL & NL & NL & $6.67 \mathrm{E} 4$ & $1.67 \mathrm{E} 3$ \\
\hline${ }^{238} \mathrm{Pu}{ }^{\text {(d) }}$ & NL & $4.7 \mathrm{E}-3$ & $2.4 \mathrm{El}$ & $5.22 \mathrm{E} 0$ & $1.3 \mathrm{E}-1$ \\
\hline${ }^{239} \mathrm{Pu}{ }^{(d)}$ & NL & $1.9 \mathrm{E}-3$ & $4.2 \mathrm{E}-1$ & $4.62 \mathrm{E} 0$ & $1.15 \mathrm{E}-1$ \\
\hline${ }^{240} \mathrm{Pu}{ }^{\text {(d) }}$ & NL & $1.9 \mathrm{E}-3$ & $4.3 \mathrm{E}-1$ & 4.62E0 & $1.15 \mathrm{E}-1$ \\
\hline${ }^{241} \mathrm{Am}{ }^{(\mathrm{d})}$ & NL & $2.1 \mathrm{E}-3$ & $8.5 \mathrm{E}-1$ & $4.44 \mathrm{E} 0$ & $1.11 \mathrm{E}-1$ \\
\hline${ }^{243} \mathrm{Cm}^{(\mathrm{d})}$ & NL & $1.8 \mathrm{E}-2$ & $3.4 \mathrm{E} 2$ & $6.67 \mathrm{E} 0$ & $1.67 \mathrm{E}-1$ \\
\hline${ }^{244} \mathrm{Cm}$ & NL & $1.4 \mathrm{E}-1$ & $1.6 \mathrm{E} 2$ & $8.57 \mathrm{E} 0$ & $2.14 \mathrm{E}-1$ \\
\hline
\end{tabular}


HNF-2804, Rev. 2

September 1999

\begin{tabular}{|c|c|c|c|c|c|}
\hline 10808 & 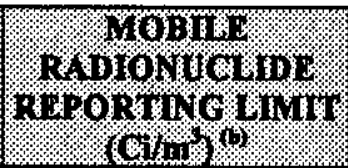 & 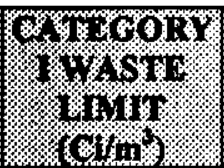 & 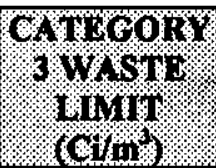 & 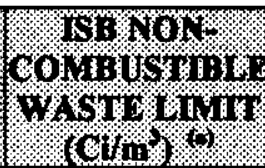 & 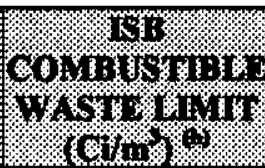 \\
\hline \multicolumn{6}{|c|}{ Site-Designated Mobile Radionuclides } \\
\hline${ }^{3} \mathrm{H}$ & 4.4E0 & 9.9E4 & NL & $4.00 \mathrm{E} 7$ & $5.00 \mathrm{E} 2$ \\
\hline${ }^{14} \mathrm{C}$ & $1.3 \mathrm{E}-4$ & $9.1 \mathrm{E}-2$ & 2.1E1 & $1.76 \mathrm{E} 6$ & 4.41E4 \\
\hline${ }^{36} \mathrm{Cl}$ & $3.1 \mathrm{E}-5$ & $6.4 \mathrm{E}-5$ & $1.4 \mathrm{E}-1$ & $1.70 \mathrm{ES}$ & 4.17E3 \\
\hline${ }^{79} \mathrm{Se}$ & $3.4 \mathrm{E}-5$ & 5.1E-1 & 1.1E2 & $3.87 \mathrm{E} 5$ & $9.68 \mathrm{E} 3$ \\
\hline${ }^{93} \mathrm{Mo}$ & $2.1 \mathrm{E}-4$ & 8.7E-1 & $2.0 \mathrm{E} 2$ & $1.28 \mathrm{E} 5$ & $3.19 \mathrm{E} 3$ \\
\hline${ }^{99} \mathrm{Tc}$ & $2.1 \mathrm{E}-4$ & $2.3 \mathrm{E}-2$ & $5.0 \mathrm{E} 0$ & $4.00 \mathrm{E} 5$ & $1.00 \mathrm{E} 4$ \\
\hline${ }^{129} \mathrm{~T}$ & $1.0 \mathrm{E}-6$ & $8.5 E-3$ & $1.8 \mathrm{E} 0$ & $7.06 \mathrm{E} 3$ & $1.76 \mathrm{E}-1$ \\
\hline${ }^{187} \mathrm{Re}$ & $3.3 \mathrm{E}-2$ & $3.6 \mathrm{El}$ & $7.8 \mathrm{E} 3$ & $6.32 \mathrm{E} 7$ & $1.58 \mathrm{E} 6$ \\
\hline Total U & $1.4 \mathrm{E}-5$ & NL & NL & NL & $\mathrm{NL}$ \\
\hline${ }^{237} \mathrm{~Np}$ & $1.1 \mathrm{E}-5$ & $6.8 \mathrm{E} 04$ & $1.5 \mathrm{E}-1$ & $2.55 \mathrm{E} 0$ & $6.38 \mathrm{E}-2$ \\
\hline
\end{tabular}

(a) Radionuclides applicable to B-Cell waste characterization, as well as site-designated mobile radionuclides, are from (HNF-EP-0063, Table A-2).

(b) $\mathrm{Ci} / \mathrm{m} 3=$ Curie per cubic meter.

(c) $\mathrm{NL}=$ Means that there is no applicable limit for this isotope.

(d) TRU isotope (half-life $>20$ years)

\subsubsection{Inputs Considered and Dismissed}

\subsubsection{Mobile Radionuclides}

Most of the 10 site-designated mobile radionuclides can be discounted through process knowledge. Due to the use of high temperature processes within the cell, such as calcination and various vitrification processes, any volatile radionuclides are not expected to be present in concentrations greater than the mobile radionuclide reporting limit. Tritium $\left({ }^{3} \mathrm{H}\right)$, which is generated from ${ }^{6} \mathrm{Li}$, is not expected to have been present in fuel used in B-Cell. ${ }^{14} \mathrm{C}$ is generated from ${ }^{14} \mathrm{~N}$ by an $(n, p)$ reaction and should not have been present in B-Cell. ${ }^{36} \mathrm{Cl}$ and ${ }^{93} \mathrm{Mo}$ are activation products and are not expected to be present in B-Cell. ${ }^{187} \mathrm{Re}$ is not normally present in fuel material, and thus, is not expected to be present in B-Cell. Uranium and ${ }^{237} \mathrm{~Np}$ are not expected to be present due to the Purex-type extraction process that was used to obtain the high-activity ${ }^{137} \mathrm{Cs}$ and ${ }^{90} \mathrm{Sr}$ used for the last large program in B-Cell. It is planned to analyze for total uranium in at least one sample to confirm that this constituent is not present in levels above the mobile radionuclide reporting limit given in HNF-EP0063 .

Two of the designated mobile radionuclides that cannot be totally dismissed are ${ }^{79} \mathrm{Se}$ and ${ }^{99} \mathrm{Tc}$. Since both of these radionuclides are pure beta emitters, and the cost and timing of the associated analytical procedures may be prohibitively restrictive, a ratioing method using ORIGEN data will be used to estimate potential concentrations of these 
site-designated mobile radionuclides. Ratioing will be done with ${ }^{241} \mathrm{Am}$.

${ }^{137} \mathrm{Cs}$ or ${ }^{90} \mathrm{Sr}$ are not acceptable for use in a ratioing method since high activities of these separated radionuclides were added to B-Cell for use in the FRG program.

The ORIGEN data is based on expected yields for reactor fuel having 20,000 megawatt-days per ton (MWD/T) exposure and 10 years of cooling, which is the type of reactor fuel most similar to that in B-Cell. The expected yields are as follows:

- ${ }^{79} \mathrm{Se}$ yield is $2.5 \mathrm{E}-7 \mathrm{Ci} / \mathrm{g} \mathrm{U}$

- ${ }^{99} \mathrm{Tc}$ yield is $8.3 \mathrm{E}-6 \mathrm{Ci} / \mathrm{g} \mathrm{U}$

- ${ }^{241} \mathrm{Am}$ yield is $1.06 \mathrm{E}-3 \mathrm{Ci} / \mathrm{g} \mathrm{U}$.

The associated ratios to be used to estimate potential concentrations of the two mobile radionuclides in B-Cell waste are:

- ${ }^{79} \mathrm{Se}$ to ${ }^{241} \mathrm{Am}$ ratio is. 0.000236

- ${ }^{99} \mathrm{Tc}$ to ${ }^{241} \mathrm{Am}$ ratio is 0.007830 .

Procedurally (324 Facility SOP 3I-SOP-REC-A-49), only 2,500 lbs of metal waste can be loaded into a given grout container. That results in $1.13 \mathrm{E} 6 \mathrm{~g}$ rack metal per grout container. The volume of a grout container is $1.43 \mathrm{~m}^{3}$, from Hanford engineering drawing, $\mathrm{H}-3-49415$. Thus, the maximum density of rack material in a grout container would be 1.14E7 $\mathrm{g} / \mathrm{m}^{3}$. This value multiplied by the average concentration of ${ }^{241} \mathrm{Am}$ reported (in $\mathrm{nCi} / \mathrm{g}$ ) for the fixed contamination layer of the B-Cell metal samples multiplied by the conversion factor of $1 \mathrm{Ci} / 1 \mathrm{E} 9 \mathrm{nCi}$ will be the estimated concentration of the given mobile radionuclide (in units of $\mathrm{Ci} / \mathrm{m}^{3}$ ). The estimated concentrations of ${ }^{79} \mathrm{Se}$ and ${ }^{99} \mathrm{Tc}$ will then be compared to the associated mobile radionuclide reporting limits presented in Table A-3 of this Appendix. If the estimated concentrations are greater than the mobile radionuclide reporting limits, then an evaluation of the disposal conditions to ensure disposal is compliant with burial ground performance objectives is performed by the waste contractor.

\subsubsection{Dangerous Waste Classification}

The B-Cell dunnage waste stream is nonregulated with respect to heavy metal content (Shelor 1999). This classification is based on the following:

1. Process knowledge that the equipment/components were not used for processing regulated materials.

2. Components are spray washed to remove dispersibles.

3. Direct analysis/paper Toxicity Characteristics Leaching Process (TLCP) evaluation of waste stream samples show the stream to be non-regulated with respect to heavy metals. 
HNF-2804, Rev. 2

September 1999

The grout containers in B-Cell are used for packaging B-Cell equipment dunnage and sifted debris resulting primarily from size-reduced racks and equipment, tools, manipulator boots and rings, plasma torch cables, electrical cords, metal components and housings, scrap metal, plastic sleevings, tygon tubing, metal cables, and other sifted debris. Sifted debris is considered items that have fallen to the cell floor and are later collected. The cell floor dispersible material has been found to exhibit mixed (dangerous) waste characteristics (DOE/RL 1998a). All items having the potential for containing floor dispersible or tank heels are required by procedure to be rinsed of visible dispersible or heel material before being placed into the grout container (DOE/RL 1998a; 3I-SOPREC-A-49).

All items having the potential of containing floor dispersible or tank heels are required to be rinsed of visible dispersible or heel material before being placed into a grout container. Rinsing is performed because the floor dispersible material has been shown to exhibit dangerous waste characteristics (DOE/RL-96-73). Items having visible process residue remaining after rinsing and items containing mixed (dangerous) waste are segregated as mixed waste (Rasmussen 1999a-1999h).

\subsubsection{Radionuclides of Concern}

Historical information was first reviewed, then used as a basis to select analytes. Table A-4, presented in Section 1.7.1 below, contains the Radionuclides of Concern, i.e., those analytes known or suspected to be present in the fixed contamination layer on the B-Cell metal samples.

\subsection{Study Boundaries}

This revised data quality process applies to characterization of the fixed contamination layer for metal samples from B-Cell. The data quality process is limited to data required for a decision regarding the waste classification of B-Cell dunnage and sifted debris that is placed in $\mathrm{HN}-200$ grout containers. This data quality process does not include characterization of B-Cell floor dispersibles or tank heels. The decision boundary is the dunnage and sifted debris from B-Cell in the 324 Facility. The boundary does not extend to other locations.

The results obtained from this characterization study, and the data obtained from a previous characterization of removable contamination in B-Cell, may be extended to provide bounding radionuclide conditions on other materials placed into grout containers for disposal, e.g., tools, manipulator boots and rings, plasma torch cables, electrical cords, metal components and housings, scrap metal, plastic sleevings, tygon tubing, metal cables, and other sifted debris. 
HNF-2804, Rev. 2

September 1999

\subsection{Decision Rules}

The primary action levels of concern are those required to meet the waste acceptance criteria. These criteria are identified in Sections 1.3 and 1.7 of this Appendix. The following decisions will be made as follows:

- If the reported analytical data meet the QA/QC requirements presented in Section 1.7 of the Appendix or have a valid explanation reported for the discrepancy, then they will be used in the overall process to perform radiological profiling of loaded, nongrouted grout containers. Otherwise, discussions will be undertaken with the Laboratory to remedy the discrepancy.

- The overall goal is to designate as much of the waste as LLW as possible. As specified by the waste contractor, an $85 \%$ assurance is needed that TRU content of the loaded grout container is less than the $100 \mathrm{nCi} / \mathrm{g}$ action level specified in the waste acceptance criteria (DOE/RL 1998b) in order for the B-Cell dunnage and sifted debris waste to be accepted as LLW. If the $85 \%$ assurance level is not reached, then the waste will have to be designated as TRU waste. If this occurs, the waste is not to be grouted prior to turnover to the waste contractor.

\subsection{Tolerable Limits on Decision Errors}

As the current waste contractor, Waste Management Hanford has imposed the criteria that the TRU content of the loaded grout containers must be known with $85 \%$ assurance that the determined value is equal to or less than $100 \mathrm{nCi} / \mathrm{g}$ for the containers to be accepted as LLW. For analytical data, the reporting will be required to be at the $95 \%$ confidence level. The QA/QC requirements given in Table A-3 provide further requirements in order to overcome any matrix effects in the radiochemical/analytical portion of the study and still meet the established waste acceptance criteria (WMH 1998).

The use of a $95 \%$ bounding value (i.e., the value for which the measurement has $95 \%$ assurance that the actual content of the container is equal to or less than the calculated $95 \%$ bounding value) on the TRU to ${ }^{137} \mathrm{Cs}$ regression is necessary for the radiological profiling of a given grout container. This is to ensure that after errors associated with the various parts of the grout container radiological profiling process are propagated through the entire process, the requirement that the TRU characterization of the container will be known with $85 \%$ assurance (The $85 \%$ assurance means that the waste is shown to have $100 \mathrm{nCi} / \mathrm{g}$ or less of TRU constituents with $85 \%$ assurance that the value is repeatable and measurable).

\subsection{Optimization of Sampling and Analysis Design}

\subsubsection{Analytical and Quality Control (QC) Requirements}

The following analytical methods and quality control (QC) requirements were mutually agreed upon by BWHC 324 Facility staff and Waste Management 
HNF-2804, Rev. 2

September 1999

Hanford and 222-S Laboratory Staff for the preparation and analysis of the fixed contamination layer on the B-Cell metal samples. They were set forth in Memorandum WMH-9953670, dated June 1, 1999 (WMH 1999).

The analytical methods and QC requirements applicable to each analysis are provided in Table A-4. The listed analytes will be measured for the sample solutions created during preparation and analysis of the samples. The customer required detection limits (CRDLs) were chosen to ensure that the requirements set forth as waste acceptance criteria (WMH 1998) will be met.

At a minimum, each analytical batch following dissolution will contain a laboratory control sample, a preparation blank, and one duplicate analysis as required by $222-\mathrm{S}$ Laboratory Quality Assurance Plan (Markel 1999). In addition, for gross alpha and metals analyses a post dissolution spike will be included in the analytical batch. Analytical results are to be reported at the $95 \%$ statistical confidence level.

The alpha balance must be closely checked and reported to BWHC. Uranium is not expected to be present through process knowledge. If the sum of the individual alpha emitters is less than the gross alpha minus gross alpha counting error, contact BWHC and conduct analysis for uranium in accordance with the table below. Take actions as necessary to minimize counting error. If the sum of the individual alpha emitters is still less than gross alpha minus gross alpha counting error, then a meeting will be called between WML and BWHC to initiate a planning session to address the issue.

ICP/MS analysis for atomic masses 243 and 244 on the acid etch solution of sample S99BW00063 will be performed. An aliquot that has been taken through the $\mathrm{Pu} / \mathrm{Am}$ separation without the addition of the ${ }^{243} \mathrm{Am}$ tracer will be used for this analysis. These results will be used to obtain a ratio of the two-curium isotopes. The Laboratory will provide in the written report the technical basis of the ratio. Previously, the ratio of ${ }^{243} \mathrm{Cm}$ (TRU) to ${ }^{244} \mathrm{Cm}$ (non-TRU) was estimated to be 1:70 ratio (Guenther et. al. 1991), using process knowledge of the fuel that was used as a source of material added to B-Cell during its operational history.

\section{Quality Control Analyses}

Laboratory Control Sample (LCS) - A known amount of analyte in a known matrix that is carried through the analytical method. This sample provides an indication of analytical method and instrument performance. Control limits for LCS recoveries are governed by historical method performance at a $95 \%$ confidence level.

Preparation Blank - A blank that has been carried through the entire dissolution and analytical process. The blank will consist of all reagents used during the dissolution of the samples. Blank values should be less than the minimum detectable activity or less than $5 \%$ of the sample result. 
Duplicate - A second aliquot of a sample that is carried through the analytical process. A relative percent difference (RPD) between the sample and duplicate results will be determined. Acceptable sample precision is usually $\leq 20 \% \mathrm{RPD}$. RPD is dependent upon counting error.

Spike - A known amount of the isotope of interest that is added to a second aliquot of sample. Spike recoveries give an indication of matrix interference (used in gross alpha analysis).

Carrier - A known amount of the naturally occurring element of interest added to the sample. The carrier demonstrates the same chemical behavior as the isotope of interest. The recovery is not reported, but is used to correct results for losses incurred during separation (used in ${ }^{90} \mathrm{Sr}$ analysis).

Tracer - A known amount of a different radionuclide than the isotope of interest added to the sample. The tracer demonstrates the same chemical behavior as the isotope of interest. The recovery is not reported, but is used to correct results for losses incurred during separation (used in ${ }^{238} \mathrm{Pu},{ }^{239 / 240} \mathrm{Pu},{ }^{241} \mathrm{Am},{ }^{243 / 244} \mathrm{Cm}$ ).

Table A-4. Analytical And Quality Control (OC) Requirements

\begin{tabular}{|c|c|c|c|c|c|}
\hline \multirow[b]{2}{*}{ 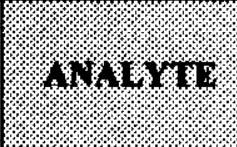 } & \multirow[b]{2}{*}{ 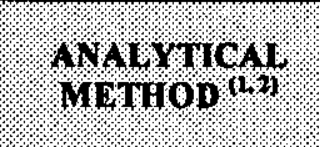 } & \multirow{2}{*}{ (a) } & \multicolumn{3}{|c|}{ 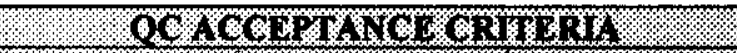 } \\
\hline & & & (\% Recover) & (1\% & PU⿴囗十. \\
\hline${ }^{137} \mathrm{Cs}$ & GEA & $1 \times 10^{-5}$ & $80-120 \%$ & N/A & $\leq 20 \%$ \\
\hline${ }^{154} \mathrm{Eu}$ & GEA & $1 \times 10^{-5}$ & N/A & N/A & $\leq 20 \%$ \\
\hline${ }^{155} \mathrm{Eu}$ & GEA & $2 \times 10^{-6}$ & N/A & N/A & $\leq 20 \%$ \\
\hline${ }^{60} \mathrm{Co}$ & GEA & $1 \times 10^{-5}$ & $80-120 \%$ & N/A & $\leq 20 \%$ \\
\hline $\begin{array}{l}\text { All detectable } \\
\text { gamma emitters } \\
\text { not listed above } \\
\end{array}$ & GEA & $1 \times 10^{-5}$ & N/A & N/A & $\leq 20 \%$ \\
\hline${ }^{90} \mathrm{Sr}$ & $\begin{array}{l}\text { Radiochemical } \\
\text { separation and beta } \\
\text { counting }\end{array}$ & $1 \times 10^{-5}$ & $80-120 \%$ & N/A & $\leq 20 \%$ \\
\hline Gross alpha & Proportional Counter & $5 \times 10^{-6}$ & $80-120 \%$ & $70-130 \%$ & $\leq 20 \%$ \\
\hline${ }^{238} \mathrm{Pu}$ & $\begin{array}{l}\text { Radiochemical } \\
\text { separation and AEA }\end{array}$ & $2 \times 10^{-6}$ & N/A & N/A & $\leq 20 \%$ \\
\hline${ }^{239 / 240} \mathrm{Pu}$ & $\begin{array}{l}\text { Radiochemical } \\
\text { separation and AEA }\end{array}$ & $2 \times 10^{-6}$ & $70-125 \%$ & N/A & $\leq 20 \%$ \\
\hline${ }^{241} \mathrm{Am}$ & $\begin{array}{l}\text { Radiochemical } \\
\text { separation and AEA }\end{array}$ & $2 \times 10^{-6}$ & $70-125 \%$ & N/A & $\leq 20 \%$ \\
\hline${ }^{243 / 244} \mathrm{Cm}$ & $\begin{array}{l}\text { Radiochemical } \\
\text { separation and AEA }\end{array}$ & $2 \times 10^{-6}$ & N/A & N/A & $\leq 20 \%$ \\
\hline${ }^{243} \mathrm{Cm}$ & ${\mathrm{ICP} / \mathrm{MS}^{(3)}}^{(3)}$ & N/A & N/A & N/A & $\leq 20 \%$ \\
\hline${ }^{244} \mathrm{Cm}$ & ICP/MS ${ }^{(3)}$ & N/A & N/A & N/A & $\leq 20 \%$ \\
\hline
\end{tabular}


HNF-2804, Rev. 2

September 1999

\begin{tabular}{|c|c|c|c|c|c|}
\hline \multirow[b]{2}{*}{ 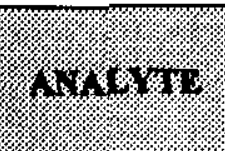 } & \multirow[b]{2}{*}{ 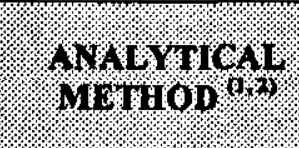 } & \multirow{2}{*}{ (1) } & \multicolumn{3}{|c|}{ 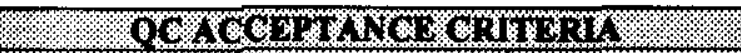 } \\
\hline & & & א. & / & \%1010\% \\
\hline $\begin{array}{l}\text { Total Uranium } \\
\text { (supplemental) }\end{array}$ & $\begin{array}{l}\text { Laser kinetic } \\
\text { phosphorescence. }\end{array}$ & $1 \mathrm{ppb}$ & $79-125 \%$ & N/A & $\leq 20 \%$ \\
\hline
\end{tabular}

GEA = Gamma Energy Analysis

AEA = Alpha Energy Analysis

ICP/MS = Inductively Coupled Plasma/Mass Spectrometry

N/A $\quad$ not applicable for this method

(1) All samples must be in a homogeneous solution prior to analysis.

(2) Sample sizes and counting techniques shall be employed that limit counting error to $<5 \%$. In the event that $<5 \%$ counting error cannot be attained, the counting error attained shall be reported and the technical basis for the inability to reach the desired maximum counting error shall be included in the report.

(3) This supplemental analysis is to be performed only on one acid etch solution (Sample No. S99BW00063) after the recovery dissolution is completed. This determination is for calculating the ratio of the two isotopes only and CRDLs are not applicable.

(4) Use of detection levels greater than the limiting customer required detection level (CRDL) listed is permissible as long as the analytical result attained to the analysis is at least 10 times the detection level used for that analysis.

Interference from the high ${ }^{137} \mathrm{Cs}$ content in this waste matrix will make reaching the listed limiting CRDL difficult for some gamma emitters (such as ${ }^{154} \mathrm{Eu},{ }^{155} \mathrm{Eu}$ and ${ }^{60} \mathrm{Co}$ ) and gross alpha. Detection levels will be minimized as much as possible in an attempt to reach the limiting CRDL specified.

If ${ }^{154} \mathrm{Eu},{ }^{155} \mathrm{Eu},{ }^{60} \mathrm{Co}$ or gross alpha are detected and the analytical result is less than 10 times the detection level used for the analysis, then the technical basis for the inability to reach the required detection level will be reported in the letter report.

If ${ }^{154} \mathrm{Eu},{ }^{155} \mathrm{Eu}$ and ${ }^{60} \mathrm{Co}$ are not detected; the detection limit must be less than $1 \%$ of the Cs result and less than $1 \%$ of the respective Category 1 limit. If either of these criteria $(<1 \%$ of the Cs result or

$<1 \%$ of the respective category 1 limit) are not met, the isotope must be reported as $<$ the detection limit used and the technical basis for the lack of ability to reach a lower detection limit must be included in the report of results.

Water wash sample Limiting CRDLs can be a factor of 10 higher than those listed, when restricted by sample volume. 